Georgetown University Law Center

Scholarship @ GEORGETOWN LAW

2013

\title{
What Consensus? Ideology, Politics and Elections Still Matter
}

Steven C. Salop

Georgetown University Law Center, salop@law.georgetown.edu

Georgetown Business, Economics and Regulatory Law Research Paper No. 13-007

This paper can be downloaded free of charge from:

https://scholarship.law.georgetown.edu/facpub/1207

http://ssrn.com/abstract=2255531

This open-access article is brought to you by the Georgetown Law Library. Posted with permission of the author. Follow this and additional works at: https://scholarship.law.georgetown.edu/facpub

Part of the Antitrust and Trade Regulation Commons, Law and Economics Commons, and the Law and Politics Commons 


\title{
What Consensus? Ideology, Politics and Elections Still Matter
}

\author{
Steven C. Salop ${ }^{1}$
}

\begin{abstract}
$\underline{\text { Abstract }}$
This article, which was prepared for an ABA Antitrust Section Panel, discusses the role of ideology and politics in antitrust enforcement and the impact of elections in the last twenty year on enforcement and policy at the federal antitrust agencies. The article explains the differences in antitrust ideologies and their impact on policy preferences. The article then uses a database of civil non-merger complaints by the DOJ and FTC over the last three Presidential administrations to analyze changes in the number, type and other characteristics of antitrust enforcement. It also discusses change in vertical merger enforcement and other antirust policies such as amicus briefs, reports and guidelines. The article concludes that elections do matter and that the impact of elections on the DOJ and FTC has differed significantly.
\end{abstract}

\section{Introduction}

In his provocative article, Theodore Voorhees asks what role politics plays in contemporary

American antitrust. ${ }^{2}$ At first glance, the answer would seem to be a simple Yes. After all, the antitrust laws are promulgated by Congress. Antitrust legal standards can be characterized as reflecting a "political bargain" among the affected constituencies. ${ }^{3}$ Political power no doubt had a major role in the legislation to grant the thirty or so statutory antitrust exemptions identified by the Antitrust

\footnotetext{
${ }^{1}$ Professor of Economics and Law, Georgetown University Law Center; Senior Consultant, Charles River Associates. This article was prepared for the Chairman's Showcase panel at the ABA Antitrust Section meetings, April 2013. I would like to thank Jonathan Baker, Thomas Barnett, Malcolm Coate, Susan Creighton, Deborah Garza, Andrew Gavil, Renata Hesse, Richard Higgins, William Kovacic, Thomas Krattenmaker, Tim Muris, Sharis Pozen, Carl Shapiro, Theodore Voorhees, John Woodbury and Joshua Wright for helpful comments on these issues. I also would like to thank my student, Christopher Sullivan, for research assistance. All remaining errors are my own. I also want to note that I acted as an economic consultant in a number of the matters discussed below. All opinions are my own and do not necessary reflect the views of these former clients.

2 Theodore Voorhees, The Political Hand in American Antitrust - Invisible, Inspirational or Imaginary (February 2013)(manuscript)

${ }^{3}$ For example, see Jonathan B. Baker, Competition Policy as a Political Bargain, 73 ANTITRUST L.J. 483 (2006); Jonathan B. Baker, Preserving a Political Bargain: The Political Economy of the Non-Interventionist Challenge to Monopolization Enforcement, 76 ANTITRUST L.J.605 (2010).
} 
Modernization Commission. ${ }^{4}$ Moreover, the Supreme Court is an inherently political body in that it uses majority rule, where outcomes are subject to the usual indeterminacy created by the Arrow Impossibility Theorem and agenda control. ${ }^{5}$ Congress and the President have the opportunity to appoint judges, DOJ AAGs and FTC Commissioners. Congress also has the ability to grill FTC and DOJ AAG nominees on their views. They also have the ability to inflict pressure on the agencies in particular cases, whether based on their own antitrust philosophy or on behalf of constituents, campaign donors or political allies.

Despite these various pressure points, Voorhees asks whether the common law model, life tenure for judges and the rise of economics might have trumped politics. He suggests that there is more of a consensus today. These are interesting hypotheses. Perhaps there are no longer any significant political issues over which there is conflict. Perhaps antitrust has become a purely economic exercise of using facts and quantitative evidence to determine the likely effects of allegedly anticompetitive conduct on consumer welfare. Using Chief Justice Roberts' analogy, maybe antitrust enforcement has become simply a matter of calling balls and strikes with the aid of objective economic evidence.

This raises a number of questions. Is there evidence that political pressure has any effect on enforcement? Do elections still even have significant effects? Is there consensus among economists or do politics and ideology matter to economists too? This article discusses these issues. Following Voorhees' approach, this article focuses particularly on Section 2 and other civil litigation involving exclusionary conduct, although other areas also are covered.

\footnotetext{
${ }^{4}$ Antitrust Modernization Commission, REPORT AND RECOMMENDATIONS (April 2007) at viii, available at http://govinfo.library.unt.edu/amc/report_recommendation/amc_final_report.pdf.

${ }^{5}$ Frank Easterbrook, Ways of Criticizing the Court, 95 HARV. L. REV. 802 (1982); Mathew Spitzer, Multicriteria Choice Processes; An Application of Public Choice Theory to Bakke, the FCC and the Courts, 88 YALE L.J. 717 (1979); David G. Post and Steven C. Salop, Rowing Against the Tidewater: A Theory of Voting by Multi-Judge Panels, 80 GEO. L. J. 743 (1992); Lewis A. Kornhauser \& Lawrence G. Sager, Unpacking the Court, 96 YALE L.J. 8282 (1986).
} 
My conclusion on the impact of elections is clear. Elections have mattered. Comparing the G.W. Bush DOJ to the Clinton and Obama DOJ, the Bush administration brought many fewer civil non-merger complaints. As for ideological focus, its enforcement record on exclusionary conduct under Section 2, Section 1 and vertical mergers was minimal. In all these dimensions, it also was less aggressive than the bipartisan FTC. The DOJ also demonstrated risk aversion by focusing more of its efforts on smaller firms and avoiding litigation, even to the point of accepting two non-binding voluntary settlements. It began by settling the Microsoft case with a weak remedy and ended with the Section 2 report. It sided with the defense side at the Supreme Court in almost every matter in a series of cases that led to more permissive antitrust standards, particularly with respect to exclusionary conduct. While the Obama DOJ has reversed direction, it has not even nearly regained the momentum of the Clinton DOJ. Whether it will do so in the second term or not, and whether a failure to do so is the result of recent Supreme Court decisions, still remains to be seen.

The remainder of this essay is organized as follows. Section II discusses the role of ideology in antitrust policy and the fact that even economists have not reached consensus. Section III addresses the issue of whether and how elections matter. This section analyzes DOJ civil non-merger complaints in detail, comparing the number, type and characteristics of enforcement over time and in comparison to the FTC. This section also examines other policy activities such as amicus briefs, guidelines and reports, and the Microsoft settlement. Section IV provides some notable examples of political pressure by Congress and the President on the Court and the agencies and their impact on antitrust doctrine. Section V concludes. The Appendix lists and classifies the DOJ non-merger civil enforcement complaints in the last 20 years.

\section{The Role of Ideology}

Partisan politics is less of a driving force in antitrust today than is ideology. By ideology, I mean the political and economic philosophy and experience that frames one's preferred enforcement policy and 
antitrust legal standards. This use of the term ideology is not intended to be pejorative. In fact, political is the more pejorative term because politics involves behavior that may be inconsistent with one's philosophy. Ideological differences can lead enforcers and courts to diverge systematically in their conclusions drawn from a given set of facts. The differences also might suggest disparities in the type of evidence deemed most relevant.

To return to the analogy of a baseball umpire, judges and commentators may not all use the same strike zone when calling balls and strikes. Their strike zones may vary because they may have differing views on the relative harms to the integrity of game from erroneous strikeouts and walks, the importance of avoiding players being beaned, and fan enjoyment from a pitching duel versus a high scoring home run derby.

Antitrust law and policy are characterized by clear differences in enforcement ideology among scholars, enforcers, commentators and courts. Former Justice Stevens and Justice Scalia obviously do not share the same view of the proper role of antitrust in the U.S. economy. The same is true for AAGs, FTC Commissioners and academics who are associated with the different "schools" of antitrust. For example, while we are both economists, Commissioner Joshua Wright and I have different ideological starting points and often disagree about cases, even when we agree on the basic facts.

There are various ways to characterize these ideological differences about the economic foundations of antitrust policy. The differences might be distilled down as follows. Chicago-school conservatives believe that markets are generally self-correcting. They believe that markets self-correct because entry almost always tends to eliminate monopoly power and collusion is very difficult to sustain in the face of incentives to defect. They also believe that industrial organization theory and factual analysis are sufficiently complex that decision making by lay juries and generalist judges is prone to error. Some also are concerned that jurors are biased against large companies and innovative business 
strategies. For these reasons, they are more concerned about false positives and over-deterrence than false negatives and under-deterrence. ${ }^{6}$

In contrast, liberals have less confidence in market self-correction. They believe that natural and strategically erected barriers to entry can deter market correction, and that empirical evidence suggests that cartels and tacit coordination are more stable in practice than some conservatives might expect. Liberals also place more weight on income distribution. They fear that even conduct that leads to efficiencies can often harm consumers, particularly lower and middle income consumers. Liberals also have a greater confidence that actions by the various arms of government can improve the both efficiency and consumer welfare. They believe that courts are no longer prone to the biases of the past. For all these reasons, they are relatively more concerned about false negatives and under-deterrence than are conservatives.

The differences in antitrust ideology cuts most sharply with respect to monopolization and exclusionary conduct more generally. Section 2 other and exclusionary conduct complaints attack the firms who were "winners" in the market, and the cases often are arise from complaints by the "losers." The winners often are the more efficient firms. Some argue that jurors are biased towards large firms and identify with the victims.

These differences in antitrust ideology sometimes may flow from broader differences in the two philosophical groups' respective concerns about economic liberty. ${ }^{7}$ Liberals seem most concerned about providing the people with protection from the powerful, and so see the state as a way to provide that protection. In contrast, conservatives seem most concerned about protection from the state itself

\footnotetext{
${ }^{6}$ For example, see Frank Easterbrook, The Limits of Antitrust, 63 TEXAS L.R. 1 (1984)

${ }^{7}$ The Chicago school of law and economics grew out of the Mont Pelerin Society, a group organized by Hayek and, as stated by George Priest, "was and to some extent still is, dedicated to the proposition that political interference with market activities is harmful to freedom." George L. Priest, The Limits of Antitrust and the Chicago School Tradition, 6 J. Competition Law \& Economics 1 (2009).
} 
and place more trust in private contracting. ${ }^{8}$ In a sense, this is a clash between the Coasian and Hobbesian views of the world. ${ }^{9}$ Conservatives see laissez-faire markets as enhancing economic liberty and economic efficiency by facilitating private cooperation and are willing to accept the economic inequality that may come with it. In contrast, Liberals see laissez-faire markets as involving highly asymmetric bargaining power and inefficient strategic behavior, leading to entrenchment of economic power and exploitation of the weak.

While these differences involve ideology, not partisan politics, they clearly can lead to a political spin. For example, in an important recent article, George Priest explains that the law and economics movement at University of Chicago "derived from what might be called a deeply held belief system that political interference in market activities interfered with freedom and reduced societal welfare." ${ }^{10}$ In his view, the underlying goal of the Chicago-school antitrust program was partially to advance the science, but "more centrally, it was to ridicule the grounds upon which courts interfered with the marketplace."11 In this regard, Priest makes the point that "the political or ideological dimension of the Coase Theorem is often ignored."12 Indeed, "Coase's ambition was to deflate arguments for more intrusive government, not - as it happened - to revolutionize our understanding of the legal system."13

These conflicts between liberal and conservative ideologies are played out across the entire range of economic regulation, including telecommunications, financial markets and transportation. They also play out in various aspects of antitrust law and policy. To illustrate, there has been an ongoing controversy over the whether the goal of an economics-based antitrust is or should be total welfare

\footnotetext{
${ }^{8}$ This sketch is over-simplified, of course. For example, some conservatives see the market as providing people with more protection from the powerful because the state often is controlled by the powerful.

${ }^{9}$ Robert Cooter, The Cost of Coase, 11 J. LEGAL STUD. 1 (1982).

${ }^{10}$ Priest, supra note 7 at 1.

${ }^{11} / d$. at 4.

${ }^{12} / d$.

${ }^{13} / d$.
} 
(i.e., efficiency) or consumer welfare. ${ }^{14}$ While it is an oversimplification, I believe that conservatives tend to favor the total welfare standard while liberals tend to favor the consumer welfare standard. The justifications given by particular commentators for their favored standard may vary, but the general tendency remains.

Jonathan Baker's analysis of the "political bargain" is an example. He suggests that economic regulatory policy, including antitrust law, has tended towards the center, balancing the goal of achieving efficiencies with a concern with income distribution. ${ }^{15}$ He views the controversy over the "appropriate" antitrust welfare standard as an example of this conflict. In Baker's view, the loosening of antitrust rules since Sylvania represents an attempt to allow greater creation of efficiencies, but the newer rules also reduce the rate of false convictions and lead to a greater incidence of false acquittals that allow firms to exercise market power. ${ }^{16}$ Therefore, Baker argues, antitrust rules reflecting political bargaining should adopt a qualified consumer welfare standard. ${ }^{17}$

Of course, Priest's article also raises an important issue of causation that makes the analysis more complex. Baker suggests that conservatives worry more about efficiency and liberals worry more about income distribution, and this divergence drives the differences in their preferred welfare standards. But, Priest's reasoning suggests that the causation might flow in the opposite direction. Conservatives may favor the total welfare standard because it implies reduced government regulation, not vice versa.

14 This discussion has become confused by the fact that Robert Bork used the term consumer welfare to describe total welfare. Robert H. Bork, THE ANTITRUST PARADOX 372-4 (1978). For one of many discussions of the confusion, see Steven C. Salop, Question: What is the Real and Proper Antitrust Welfare Standard? Answer: The True Consumer Welfare Standard, 22 Loyola Consumer L.R. 336 (2010)

15 Jonathan B. Baker, Economics and Politics: Perspectives on the Goals and Future of Antitrust, 81 Fordham L. Rev. 2175 (2013).

16 Id. at $110-111$.

17 The qualification is that firms should be permitted to capture large increases in producer surplus if the losses in consumer surplus are small. Id. at 112. This corresponds to the Merger Guidelines approach to inextricably linked efficiencies. 
Whichever the direction of the causation, these ideological differences can play themselves out, even beginning from a common conceptual and factual starting point. For example, both Commissioner Joshua Wright and I begin with the foundational role of decision theory in setting antitrust standards. We also both favor the use of evidence. ${ }^{18}$ But, we may differ with respect to how much evidence should be required and which side should have the burden. Even putting aside any disagreements about the antitrust goal and assuming that we both observe the same facts, we still may disagree about particular cases where the effects are not certain. We may disagree about whether the conduct is presumptively procompetitive or anticompetitive. Even if we agree on the direction of the presumption, we still may disagree about the strength of the presumption. We also may disagree about the relative importance of false positives and over-deterrence versus false negatives and under-deterrence, which will affect our respective burdens of persuasion placed on the plaintiff versus defendant. We likely would agree about what efficiencies should be deemed legitimate. But, we may disagree about the ability to achieve legitimate efficiencies absent the restraint in question. These disagreements also may inadvertently affect into our evaluation of the evidence itself. He might suggest that I am overly critical of the benefits evidence while being overly accepting of the harm evidence, and I might suggest that he is doing the opposite. For all these reasons, he might reject a liability finding in a particular case where I might find liability.

Politics and ideology are fundamentally different. Politics is focused on obtaining votes, not maintaining a philosophy. Ideological positions must be consistent. In contrast, political positions sway with the wind. Indeed, political behavior is clearest when an individual makes a decision or takes a position that is inconsistent with his ideology. However, because politicians often do have underlying

\footnotetext{
18 Joshua D. Wright, Abandoning Antitrust's Chicago Obsession: The Case for Evidence-Based Antitrust, 78 ANTITRUST L.J. 241 (2012); Thomas G. Krattenmaker and Steven C. Salop, Anticompetitive Exclusion: Raising Rivals' Costs To Achieve Power over Price, 96 YALE L.J 209 (1986).
} 
philosophies, politics and ideology interact. In this regard, Republicans tend to be more conservative and Democrats more liberal with respect to antitrust and other forms of market regulation.

This focus on ideological differences is not intended to claim that partisan or constituent politics never matters, or that political pressure is never exerted. Both have been important determinants of outcomes, as discussed below. As noted earlier, one way to identify the role of politics is when a politician takes a position that appears inconsistent with his ideology. For example, President Reagan took a conservative approach to antitrust, appointing William Baxter as AAG and generally supported the DOJ's controversial efforts to loosen vertical restraints law. However, he did not veto the bill that prohibited the DOJ from participating in the oral argument in Monsanto. He also famously deviated from his ideology with respect to the FCC's Financial Interest and Syndication Rules. These rules prevented the TV networks from gaining more control over syndicated programming by banning certain vertical restraints in the contracts. Both the FCC and the DOJ in the early 1980s supported termination of these rules. In this fight between the New York TV networks and the Hollywood studios, President Reagan sided with Hollywood. He intervened and announced a 2-year moratorium on rule changes on any changes to the rules, despite opposition from the DOJ and the FCC. ${ }^{19}$

Just as ideology can be trumped by the Presidential or Congressional politics, ideology also can be trumped by the needs of a lawyer's constituents. This is change driven by economic self-interest instead of votes or compaign contributions. The controversy over Section 2 provides a good example. Former Reagan AAG Charles ("Rick") Rule has been an important conservative ideological opponent of Section 2, as well as outside counsel for Microsoft. In his testimony submitted to the Antitrust Modernization Commission in 2005, for example, he opined that consumer welfare would be increased

\footnotetext{
${ }^{19}$ For one review, see Christopher J. Pepe, The Rise and Fall of the FCC's Financial Interest and Syndication Rules, 1 JEFFREY S. MOORAD SPORTS L.J. 67, n. 46 (1994), available at http://digitalcommons.law.villanova.edu/mslj/vol1/iss1/5/?utm_source=digitalcommons.law.villanova.edu\%2Fmsl j\%2Fvol1\%2Fiss1\%2F5\&utm_medium=PDF\&utm_campaign=PDFCoverPages.
} 
if Section 2 were repealed or at least greatly restricted. ${ }^{20}$ But, five years after his AMC testimony, Rule's continued representation of Microsoft led him to change his public position in a dramatic way. In a 2010 Wall Street Journal Op Ed piece ironically entitled "Trust Us Isn't An Answer," he opined that "the last 10 years have shown that reasonable antitrust rules can be applied to prevent exclusionary conduct by dominant tech firms without destroying market forces." ${ }^{21}$ In contrast to his previous recommendations to the AMC in 2005 that Section 2 be repealed or significantly restricted, Rule now recommended that an antitrust case should be brought against Google. ${ }^{22}$ This U-Turn would seem more to reflect the interests of himself and his client, Microsoft, not a change in his underlying antirust philosophy. Of course, this example also speaks to the role of lawyers versus expert economists. If an expert witness changed his views in this way, a detailed explanation would be required to reconcile the apparently divergent views. ${ }^{23}$ If he did not, he would lose his credibility and his views would no longer be taken seriously. ${ }^{24}$

${ }^{20}$ Charles F. (Rick) Rule, The Section 2 "Mess": Do We Really Need It or Can We at Least Make It Better?, Written Submission to the Antitrust Modernization Commission 12 (Sept. 29, 2005) at 12. I noted at the time that he wanted to "fix" Section 2 in the same way that one "fixes" a cat.

${ }^{21}$ Charles F. (Rick) Rule, 'Trust Us' Isn't an Answer, Wall Street Journal (September 17, 2010), available at http://online.wsj.com/article/SB20001424052748703466704575489582364177978.html?cb=logged0.2032491121 1508823.

22 Rick Rule, Former Head of DOJ Antitrust Division: Google's Conduct Threatens the Free Market, available at http://www.fairsearch.org/general/former-head-of-doj-antitrust-division-googles-conduct-threatens-the-freemarket/. (In this regard, I was not involved in the FTC's investigation or related matters for either side. I consulted with Google in the Google/Motorola merger and with Yahoo in the proposed Google/Yahoo venture. I also consulted with the DOJ in its investigation of the Google/ITA merger and raised concerns about that transaction.)

${ }^{23}$ For a similar critique of Rule's article, see Josh Wright, Antitrust Karma, the Microsoft-Google Wars, and a Question for Rick Rule. Blog Post, Truth on the Market (September 19, 2010), available at http://truthonthemarket.com/2010/09/19/antitrust-karma-the-microsoft-google-wars-and-a-question-for-rickrule/;

${ }^{24}$ Thomas Barnett, the AAG that issued the DOJ's Section 2 report, may provide something closer to the expert witness model. In testimony to the Senate Judiciary Committee on behalf of his client, Expedia, he testified on the basis of his antitrust experience that the FTC or DOJ should bring a monopolization complaint against Google for its anticompetitive exclusionary conduct. Statement of Thomas O. Barnett, Hearing on Competition in Online Markets/Internet Search Issues (September 21, 2011), available at http://www.judiciary.senate.gov/pdf/11-921BarnettTestimony.pdf. In a subsequent panel sponsored by the Federalist Society, he even raised the specter of a Google breakup remedy. See Declan McCullagh, What an Anti-Google Antitrust Case by the FTC Would Look Like, 


\section{Do Elections Matter?}

The discussion above explains how difference in ideologies can affect attitudes towards antitrust enforcement. Therefore, it would be no surprise if elections had significant effects on agency enforcement. Voorhees suggests that the influence of elections on agency enforcement has declined. If a basic consensus in antitrust has emerged and the state of the law were stable, then the influence of elections would be waning. For example, while DOJ voting rights changes enforcement might vary significantly across administrations, its enforcement of federal kidnapping laws does not. However, if ideology remained important, then there might be large differences, particularly regarding monopolization and exclusionary conduct.

Voorhees' hypothesis that elections no longer matter is not consistent with my review of the evidence. While there is a broad antitrust mainstream, there have been significant differences in the enforcement records of the two political parties in recent years that likely have been driven by different antitrust ideologies. Analysis of the number, type and other characteristics of DOJ civil non-merger complaints, both over time and in comparison to the FTC, indicate that there have been significant differences in the DOJ enforcement records across the three administrations,. These results indicate that elections do matter. Of course, commentators may disagree about whether these differences amount to better or worse antitrust enforcement.

At the same time, I also do not find this effect of elections at all disturbing. Antitrust has an important role in the regulation of our economic system. It can affect the vitality of the competitive

available at http://news.cnet.com/8301-13578_3-57539837-38/what-an-anti-google-antitrust-case-by-the-ftcmay-look-like/. Barnett did not cite to the (then withdrawn) DOJ's Section 2 report in this Senate testimony, only the AMC report. I expect that he believes is that there are no inconsistencies between his testimony and the Section 2 report, though he has not responded explicitly to criticisms that have been made. For example, Joshua Wright, then a Google consultant, has suggested a number of conflicts that would need to be explained. See Barnett v. Barnett on Antitrust Truth on the Market (May 11, 2011), available at http://truthonthemarket.com/2011/05/10/barnett-v-barnett-on-antitrust/. 
process, the speed of innovation, the distribution of income, and the efficiency of the market. ${ }^{25}$ No one would say that tax policy or climate change policy should be unaffected by elections, and antitrust policy is no different.

This argument that antitrust is "just" law enforcement (or just economics) and, therefore, should not vary by administration applies in a limited way. Criminal cartel enforcement only varies across administrations according to the number of crimes that are detected, in much the same way that bank robbery enforcement policy is not ideological. ${ }^{26}$ But, as discussed above, much of civil antitrust is not just "calling balls and strikes." The size of the strike zone is a policy decision for both enforcers and courts in the common law system that governs antitrust.

The next question is whether and how much elections matter for antitrust enforcement. I analyze this issue with respect to the number, type and other characteristics of DOJ civil non-merger actions. I compare the DOJ enforcement record over time. I also use the FTC record as a point of comparison to the DOJ. I also discuss other areas of enforcement and policy.

My study used DOJ press releases to identify complaints. ${ }^{27}$ I then examined the complaints to determine the nature of the allegations (whether collusive, exclusionary, or both) and whether the complaint alleged a violation of section 1 , section 2 or both. ${ }^{28}$ I include only matters in which there

\footnotetext{
${ }^{25}$ Antitrust also reflects and defines norms of "proper" business conduct, though the declaration of such values is no longer considered a primary purpose of antitrust rules.

${ }^{26}$ I have not studied criminal enforcement for this article, but am only reporting the general view.

${ }^{27}$ Some previous studies have counted complaints by using the DOJ workload statistics.See Antitrust Division Workload Statistics 2002-2011, available at http://www.justice.gov/atr/public/workload-statistics.html. For example, Daniel Crane used the workload statistics to compare the G.W. Bush and Obama administrations. In the last two years of the G.W. Bush administration (2007-2008), the DOJ filed 3 non-merger civil complaints. During its 2009 ramp up year, the Obama administration brought no cases. But, in the first two full years of 2010-2011, the Obama DOJ brought 7 cases. Daniel A. Crane, Has The Obama Justice Department Reinvigorated Antitrust Enforcement?, 65 STAN. L. REV. ONLINE 13 July 18, 2012, available at http://www.stanfordlawreview.org/sites/default/files/online/articles/65_Stan._L._Rev._Online_13.

${ }^{28}$ It is interesting to note that none of the 3 administrations brought any complaints during their transition years. There were no complaints counted in Calendar 1993, 2001 or 2009. This may reflect the previous administration clearing out its inventory of viable investigations before it leaves. Or, it may take a new administration a period of time to set its priorities and carry out its own investigations.
} 
were complaints and do not include Business Review Letters or matters that were resolved without a complaint. $^{29}$ The number and characteristics of the DOJ complaints are summarized in Table 1 . The DOJ complaints are listed in Table 4 in the Appendix. ${ }^{30}$

\begin{tabular}{|c|c|c|c|c|c|}
\hline & $\begin{array}{c}\text { Clinton } \\
(1993-2000)\end{array}$ & $\begin{array}{l}\text { G.W. Bush } \\
\text { (2001-2008) }\end{array}$ & $\begin{array}{l}\text { G.W. Bush } \\
\text { (2005-2008) }\end{array}$ & $\begin{array}{l}\text { G.W. Bush } \\
\text { (2001-2004) }\end{array}$ & $\begin{array}{c}\text { Obama } \\
\text { (2009-2012) }\end{array}$ \\
\hline Collusive & 20 & 13 & 7 & 6 & 8 \\
\hline Exclusionary & 21 & 3 & 3 & 0 & 2 \\
\hline Both & 7 & 0 & 0 & 0 & 1 \\
\hline Total & 48 & 16 & 10 & 6 & 11 \\
\hline
\end{tabular}

${ }^{29}$ This raises the issue of the proper division between business review letters and informal advice versus law enforcement. I have taken a bright line approach. I do not count Visa's voluntary and non-binding decision to rescind its debit card rule in 2008. I also do not count the voluntary abandonment of the Google/Yahoo advertising agreement in 2008. (This latter agreement arguably also would have fit more closely into the merger category because it was a joint venture to partially combine.) See DOJ Press Release, Visa Inc. Rescinds Debit Card Rule As A Result Of Department Of Justice Antitrust Investigation, available at http://www.justice.gov/atr/public/press_releases/2008/234577.htm; DOJ Press Release, Yahoo! Inc. and Google Inc. Abandon Their Advertising Agreement, available at http://www.justice.gov/atr/public/press_releases/2008/239167.htm. (I consulted for Yahoo in the Google/Yahoo matter.) I discuss these voluntary settlements in more detail below.

${ }^{30}$ These complaint lists were developed by reviewing the DOJ website for press releases and other sources. This data is organized by Calendar Years, not Fiscal Years. (However, because there were no complaints counted in Calendar 1993, 2001 or 2009, this convention does not change the totals for each administration. (In this regard, the Clinton DOJ total does not include the 1993 Canstar Sports USA consent decree. The Consent Decree is dated March 17, 1993 and AAG Ann Bingaman was not officially nominated until April 29, 1993). The list reflects my judgment calls regarding whether groups of complaints should be treated as separate complaints. I generally collect complaints despite there being multiple defendants or settlements of the same matter that take place over time. For example, the Obama DOJ complaints against Visa, MasterCard and American Express are treated as a single case, as are both the earlier litigation against Visa and MasterCard during the Clinton administration and the recent eBooks litigation. The Obama DOJ complaint against eBay in 2012 originated in the 2010 employee poaching complaints that involved Lucasfilm and other companies, but it is treated as separate, based on my understanding from a DOJ official that the eBay matter involved a separate investigation. The G.W. Bush MLS complaints similarly are treated as separate matters, based on my understanding from a DOJ official that they were treated as independent of one another. I treated the separate KeySpan and Morgan Stanley complaints as a single case. It was suggested to me by a DOJ official that there were separate issues involved in the disgorgement remedy for Morgan Staley, so my decision arguably undercounts the Obama complaints by 1 . 


\section{A. Total Number of DOJ Complaints}

I focus first on the total number of complaints brought by each administration. In carrying out this analysis, I basically concur with William Kovacic that counting complaints alone is not sufficient to evaluate the beneficial productivity of the enforcement agency. ${ }^{31}$ However, the use of complaint counts here is intended to indicate the differences in agency behavior over time. Complaint counts seem like a useful measure for this purpose, subject to the issues discussed below. In addition, I go beyond the numbers and discuss the characteristics of the complaints as well.

One issue is that the supply of potentially problematical conduct is not exogenous. It depends on the state of the law and law enforcement. For example, as discussed below, the first term Obama DOJ brought more complaints than did the first term G.W.Bush DOJ, but many fewer complaints than did the Clinton DOJ during its first term. This raises the question of why the number of complaints in Obama's DOJ's first term have not returned nearly to the Clinton level, particularly in light of the rhetoric of AAG Varney when she took office.

One possible answer is that mainstream antitrust ideology has moved significantly in a conservative direction, so that even a Democratic administration would find it appropriate to bring fewer complaints. Another possible answer is that antitrust law itself has changed dramatically, so that there are fewer antitrust violations to attack. Of course, this latter answer does not mean that ideology is irrelevant. To the contrary, the changes in antitrust law may be driven by the ideology of the courts, particularly the Supreme Court. And, those changes may have driven or supported by DOJ Amicus briefs.

${ }^{31}$ William E. Kovacic, Rating the Competition Agencies: What Constitutes Good Performance?, 16 GEO. MASON L.R. 903 (2009). 
Moreover, as discussed below, the possible answer that it is solely changes in the law that has led to fewer antitrust violations is problematical. Suppose that the loosening of merger enforcement over the years has led to more mergers being attempted than previously, transactions that would have been deterred by fear of enforcement. Nonetheless, if merger enforcement were perfectly predictable, there would be no challenges, regardless of the DOJ's enforcement standard. Firms would propose deals right up to the current line and no further. ${ }^{32}$ This analysis suggests that there are only violations when the law or law enforcement is uncertain, or when there are errors. Economists refer to this analysis as a selection effect. ${ }^{33}$

According to this reasoning, enforcement rates would fall when firms and their counselors are surprised by the unexpected leniency of the administration relative to the law, and vice versa. ${ }^{34}$ This selection effect is weakened, of course. if the complaints involve conduct that was initiated during the previous administration. But, if a significant selection effect remains, then the interpretation of the counts would change. A low rate of complaints would mean that potential defendants were pleasantly surprised by the permissiveness of the administration, relative to their expectations. A high rate of complaints would mean that the potential defendants were unpleasantly surprised by the hostility of the administration.

Looking backwards over time at the total number of complaints, the Clinton DOJ over its two terms brought many more such complaints than did the G.W. Bush administration over its two terms.

\footnotetext{
32 If Jaywalking were per se illegal and subject to a mandatory death penalty, there would be few if any jaywalking complaints.

${ }^{33}$ There is an extensive literature on this point. For two important articles, see George Priest and Benjamin Klein, The Selection of Disputes for Litigation, 13 J. LEGAL STUD. 1 (1984); Joel Waldfogel, The Selection Hypothesis and the Relationship between Trial and Plaintiff Victory, 103 J. Pol. Econ. 229 (1995). The selection effect also suggests that a high loss rate by the agencies does not imply agency over-reaching of the law but rather flows from asymmetric stakes. For example, see Steven C. Salop \& Lawrence White, Economic Analysis of Private Antitrust Litigation, 74 GEO. L.J. 1001, 1031 (1986).

${ }^{34}$ For a similar analysis, see Jonathan Baker and Carl Shapiro, Reinvigorating Horizontal Merger Enforcement, in Robert Pitofsky (ed.), WHERE THE CHICAGO SCHOOL OVERSHOT THE MARK: EFFECT OF CONSERVATIVE ECONOMIC ANALYSIS ON U.S. ANTITRUST 235, 245-247 (2008).
} 
According to my count, the Clinton DOJ brought 48 complaints. In contrast, the G.W. Bush DOJ brought only 16 complaints. ${ }^{35}$ So, either the Bush administration was more lenient than the Clinton administration, or more lenient than potential defendants expected, or both. Since the business community and outside counsel probably did expect more lenient antitrust enforcement under G.W. Bush, then the selection effect would imply a double-whammy, that is, the Bush DOJ must have been even more lenient than the greater leniency expected to occur.

Returning to the counts, I also compared the first term Obama DOJ to the first term G.W. Bush DOJ. I compared the first terms for each because it always takes a while for each administration to get up to speed and none of the AAGs brought any complaints during the first year of a new administration. So, comparing G.W. Bush's second term to Obama's first term does not seem like an apples-to-apples comparison.

The Obama DOJ brought 11 complaints during their first term. This compares to 6 complaints during the first 4 years of the G.W. Bush administration. ${ }^{36}$ Thus, the Obama DOJ so far is running at a higher rate than the DOJ during the first term of G.W. Bush. But, the Obama DOJ is certainly far below the number of complaints brought during the first term of the Clinton administration. In addition, the G.W. Bush DOJ brought 10 complaints during its second term versus only 6 complaints in its first term. This data also raises the question of how the selection effect would affect the interpretation of the results. The increase in Obama complaints over G.W. Bush complaints could be said to indicate that potential defendants were a bit surprised by the possibly tougher stance of the new administration.

\footnotetext{
35 According to the DOJ Workload Statistics, the Clinton DOJ filed 50 Section 1 complaints and 8 Section 2 complaints. The difference may involve some double counting of complaints with multiple allegations in the workload statistics. In contrast, it reports that the G.W. Bush DOJ bought 16 Section 1 complaints and zero Section 2 complaints. One other possible reason for the differences is that I use Calendar Years instead of Fiscal Years. Because there were no complaints that I counted in Calendar 1993, 2001 or 2009, this will not change the totals for each administration, only for each year. Differences also may be caused by variations in the way of counting complaints with multiple defendants.

${ }^{36}$ I compare the first term of each because the first year of the first term has been ramp up year for each of these administrations. There were no complaints brought by the new administration either in 1993, 2001, or 2009.
} 
But, the selection effect is unlikely to explain the huge difference between the Clinton and Obama case loads. There was some rhetoric by the Obama team that the DOJ would be getting tougher than previously. But, with its complaints against NASDAQ, GE, Microsoft, Visa and MasterCard, American Airlines and Dentsply, the Clinton DOJ built a credible reputation for litigation that would be unlikely to leapfrog with just rhetoric. And the Obama DOJ has not yet established that reputation in its first term.

Finally, one issue raised by this review of the respective enforcement records is whether the differences are the serendipitous result of complaints that came through the door or whether they reflect decisions based on divergent ideologies. Ideology seems like a major factor. Looking at the Clinton DOJ complaints, it seems unlikely to me that the G.W. Bush DOJ would have brought the Microsoft case, and certainly would not have proposed a structural remedy if it did. It similarly seems unlikely that it would have brought the American Airlines predatory pricing/capacity expansion case. Visa would be a closer call because it involved concerted action. The Bush DOJ pursued the appeal in Dentsply, but whether it would have filed the complaint t originally is a separate question.

Looking at the Obama DOJ complaints, my expectation is that the employment poaching complaints probably would have been pursued by the Bush DOJ. The investigation of the Keyspan/Morgan Stanley agreement was initiated during the Bush administration. No complaint was filed, but Deborah Garza, who was Acting AAG at the end of the G.W. Bush administration, has said that she supported this complaint - and the aggressive disgorgement remedy. I expect that the eBooks litigation would be a closer call if the horizontal agreement were not a certainty. Or to state it more precisely, now that the publishers have settled, and if DOJ were to accept Apple's argument that Apple was not privy to the discussions among the book publishers, would the matter have been litigated by the Bush DOJ. I am asking this question because that case would amount to an attack on the combination of RPM and MFNs adopted through parallel vertical agreements. In addition, the Bush DOJ seemed adverse to litigation. 
However, I do want to emphasize that these are just my predictions. It would be very

interesting to have the former AAGs themselves explain what led to their case selection criteria and why they brought certain complaints and did not bring others. They also could opine about the complaints of other AAGs that they would or would not have brought and why. That process could give a much deeper understanding of any deological differences.

\section{B. Exclusionary Conduct Complaints}

Ideological differences are greatest with respect to monopolization and other exclusionary conduct, so I also analyzed the allegations of the complaints. Voorhees suggests that Section 2 enforcement policy may not have changed significantly at the DOJ as a result of change in administration. He specifically makes the point that the Obama administration has brought only one Section 2 complaint and it did not involve a prominent defendant, despite AAG Varney's rhetoric in withdrawing the Bush administration's Section 2 report in $2009 .^{37}$

To test this hypothesis, I classified the complaints according to whether they alleged a violation of section 1 or section 2 of the Sherman Act, or both sections. I also classified the complaints according to the whether the complaints alleged on collusive conduct (i.e., elimination of competition among the defendants) or exclusionary conduct (i.e., conduct intended to exclude competition by non-parties), or both. ${ }^{38}$ There are large differences in the number of exclusionary conduct complaints and the breakdown between collusive and exclusionary conduct complaints.

\footnotetext{
37 The one monopolization case involved United Regional Health Care System of Wichita Falls, Texas. For the press release, see http://www.justice.gov/opa/pr/2011/February/11-at-249.html

${ }^{38}$ I also identified whether the complaints focused on vertical price fixing (resale price maintenance). The RPM case counts are not surprising. Even while vertical price restraints law was becoming more permissive, the Clinton administration brought more such complaints, 8 for the Clinton DOJ versus none for the Reagan/Bush DOJ. Perhaps more surprisingly, the Obama DOJ has not brought any standard RPM complaints under the Leegin rule of reason standard. However, there is a caveat here. The Apple/eBook publishers case does involve resale price maintenance. The difference from Leegin is, of course, that the adoption of the RPM allegedly involved a horizontal conspiracy as well as vertical agreements. However, in the event that Apple is the only defendant left standing, I expect that the purely vertical issues will take on a greater importance. See Kovacic, supra note 30 at
} 
I counted 9 complaints with Section 2 counts brought by the Clinton DOJ. ${ }^{39}$ In contrast, Kovacic and Muris each reported that the DOJ brought only 2 such complaints during the twelve years of the Reagan/G.W.H Bush administrations. ${ }^{40}$ There were no Section 2 complaints brought by the DOJ during the G.W. Bush administration.

It is useful to widen the focus here beyond just Section 2 to exclusionary conduct allegations brought under Section 1 as well as Section 2. The controversy among antitrust commentators - and the ideology behind the DOJ's Section 2 report - involves the concerns raised by exclusionary conduct generally, not simply exclusionary conduct that might violate Section 2. Exclusionary conduct may be carried out by the unilateral conduct of monopolists. But, exclusionary conduct also may occur in vertical mergers or agreements that might be attacked under Section 1.

This broader focus affects the scorecard even more. Among the 48 Clinton complaints, 21 involved exclusionary conduct and 7 involved exclusionary as well as collusive conduct, for a total of 28 with exclusionary conduct allegations. This is significantly more than half of the Clinton complaints. These complaints included the gamut of exclusionary conduct (e.g., predatory pricing, contractual and physical tying, exclusive dealing, MFNs, exclusionary group boycotts, and so on). A number of these complaints were criticized at the time as being novel or over-reaching.

460 (Table 5). My count had 3 RPM complaints by the Clinton DOJ, excluding the Canstar Sports matter. But there are other types of vertical restraints besides RPM that I did not break out.

${ }^{39}$ See Table 2 in the Appendix for a listing of the complaints. The Antitrust Division Workload statistics reports 8 complaints. According to the data collected by William Kovacic and Timothy Muris, the Clinton DOJ brought 7 monopolization and attempted monopolization complaints. Kovacic, supra note. 30 at 449 (Table 4) (2003); Timothy J. Muris, How History Informs Practice - Understanding the Developments of Modern U.S. Competition Policy (November 19, 2003), available at http://www.ftc.gov/speeches/muris/murisfallaba.pdf. However, commentators may differ on the exact counts because some complaints allege violations of Section 1 as well as Section 2 or because they involve separate complaints against multiple defendants. The Muris data also is reported on an annual basis with only a single decimal point, so the Clinton result of 0.9 could indicate 7 or 8 complaints. These caveats suggest that small differences are not surprising. Nor do they change the basic conclusion.

40 Id. The Data reported in a speech by Chairman Muris indicates that the Reagan DOJ brought 2 Section 2 complaints while the G.W.H Bush administration brought none. Muris' results from the FTC also showed the same contrast: 2 during Reagan; zero during G.W.H. Bush; 4 during Clinton. 
In contrast, the G.W. Bush administration brought only 3 exclusionary conduct complaints.

These complaints all involved multiple listing services. One targeted the National Association of Realtors and the other two targeted local multiple listing services. These were all brought during the second term.

The Obama DOJ administration has only one Section 2 complaint during its first term. However, the Obama DOJ has brought several significant Section 1 complaints that allege exclusionary conduct. There were 3 exclusionary conduct matters during the first term, 2 that were purely exclusionary and one that was both collusive and exclusionary. In contrast, the G.W. Bush DOJ had none during the first term.

The exclusionary conduct allegations in several of the Obama DOJ complaints have focused on MFNs. The complaint against Blue Cross and Blue Shield of Michigan alleges that the dominant insurer used most MFN provisions to exclude rivals in order to maintain its market power. ${ }^{41}$ The DOJ also brought Section 1 exclusionary conduct complaints against the credit card companies for agreements involving MFNs. Visa and MasterCard settled, while the American Express case is still headed to trial. The economics of the allegations in the eBooks complaint involves the combined use of MFNs and RPM as exclusionary conduct to harm consumers by disadvantaging Amazon's business strategy relative to Apple. ${ }^{42}$ The Wichita Falls Section 2 complaint concerns loyalty discounts.

\section{Risk Aversion in Enforcement}

41 The fact that these complaints were brought until Section 1 instead of Section 2 also raises another confounding issue regarding the impact of politics and elections on antitrust enforcement. Over the past two decades, with the aid of Amicus briefs from the agencies during Republican administrations, the Supreme Court has made it significantly more difficult for the agencies to win monopolization complaints. Brooke Group, Trinko, linkLine and Weyerhaeuser have tightened the standards for predatory pricing, refusals to deal, price squeezes and predatory overbuying. Therefore, the agencies understandably may have been reluctant to bring Section 2 complaints where Section 1 would suffice.

42 This analysis can be placed in the exclusionary conduct framework set out in Leegin. Leegin Creative Leather Products, Inc. v. PSKS, Inc., 551 U.S. 877,894 (2007)(use of RPM to forestall innovation or exclude smaller rivals or new entrants). 
There also are apparent differences in the riskiness of the complaints among the administrations. More of the Clinton DOJ complaints involved complaints with seemingly more risky theories and brought against better financed national entities. For example, the Clinton DOJ brought complaints against Microsoft, Visa, ${ }^{43} \mathrm{GE}$, American Airlines, and NASDAQ. A number of these were high profile, complex complaints. In comparison, the G.W. Bush DOJ was more conservative. It generally brought less risky complaints. It also failed to litigate any complaints after its loss in the Oracle/PeopleSoft merger, a fact which also is consistent with greater risk aversion. ${ }^{44}$

The size of the defendants is relevant for two main reasons. First, litigation against larger companies is more visible and so has greater deterrence effects. Such cases also often generate more consumer benefits because more people and more revenue is affected. So, size is a relevant measure of enforcement intensity. Second, larger national firms generally have deeper pockets, which creates a greater threat of litigating and litigating more intensely than are the smaller ones. These firms also are more likely to be repeat players in the litigation threat game, which also gives them an incentive to play hard ball. So, the size difference among the defendants also may indicate a certain greater risk aversion by the Bush DOJ.

This issue of possible risk aversion also might usefully be applied to the two 2008 matters (the Visa rule and the Google/Yahoo advertising agreement) that the DOJ resolved informally without a complaint (and that I did not include in my counts). While the DOJ may have threatened litigation, taking this voluntary settlement would have significantly reduced the DOJ's risk of having to go to trial. A complaint and consent decree in the Visa matter likely would have alleged that Visa had market power, that the proposed rule was a violation of Section 1 and that Visa was not simply a single entity imposing a vertical restraint. Having these allegations in a complaint may have materially weakened

43 United States v. Visa, U.S.A., Inc., 344 F.3d 229 (2d Cir. 2003), cert. denied, 543 U.S. 811 (2004)

44 For example, see James A. Keyte, United States v. H\&R Block: The DOJ Invokes Brown Shoe to Shed the Oracle Albatross, 26 ANTITRUST 32 (2012) 
Visa's position in the class action litigation and other matters. Thus, it would have been less likely to settle and more likely to take the case to trial. Similarly, in Google/Yahoo, a complaint and consent decree likely would have required a search market to be defined and high market shares to be calculated. Again, the parties likely would have been more reluctant to settle, which then would have forced the DOJ into risky litigation or be forced to cave. The informal agreements were a way for DOJ to eliminate these litigation risks.

However, such non-binding informal agreements constitute less effective law enforcement and provide less deterrence. While such informal actions do terminate the immediate conduct, they also carry less weight because they cannot be used by the agencies or third parties in future proceedings. They also reduce deterrence because they prevent the parties from proposing anticompetitive activities at no risk. This conclusion does not seem controversial. Indeed, if informal settlements were considered equally effective, then it raises the question about why agencies should ever issue complaints and require consent decrees for matters that could be resolved informally by such gentlemen's agreements.

The Obama FTC recently accepted a similar non-binding voluntary commitment from Google that raises these same issues. ${ }^{45}$ Commissioner Rosch condemned this remedial approach as ineffective law enforcement. ${ }^{46}$ He also pointed out that it was criticized by the ABA Committee on the FTC back in 1969. ${ }^{47}$ Voluntary commitments are accepted by the European Commission under Article 9 of Regulation $1 / 2003$. While they also avoid a formal complaint, they are legally binding.

\footnotetext{
${ }^{45}$ The FTC Press Release is available at http://www.ftc.gov/opa/2013/01/google.shtm. The Google commitment letter is available at $\mathrm{http}: / / \mathrm{www} . \mathrm{ftc} . \mathrm{gov} / \mathrm{os} / 2013 / 01 / 130103$ googleletterchairmanleibowitz.pdf.

${ }^{46}$ Concurring and Dissenting Statement of Commissioner J. Thomas Rosch Regarding Google's Search Practices (January 3, 2013) at 6-8, available at http://www.ftc.gov/os/2013/01/130103googlesearchroschstmt.pdf. Commissioner Rosch also did not believe that Google violated the law.

${ }^{47}$ Id. at n.16.
} 
The Obama DOJ has been in-between with respect to risk-taking and cutting-edge theories.

Some of its complaints raised more novel issues. Several involved MFNs. The complaint against Apple and the top book publishers involved collective action to adopt RPM and MFNs, a complaint that is could be very controversial, absent a horizontal agreement. The complaints against Keyspan and Morgan Stanley were the first use of a disgorgement remedy by the DOJ. A number of the Obama complaints have involved deep-pocket national competitors that might be expected to litigate, including Apple, American Express, Visa and MasterCard, and the high tech Silicon Valley firms accused of employee market division. However, it has not achieved a level of enforcement nearly approaching the Clinton DOJ.

\section{Comparison to FTC Enforcement}

One of the other questions raised in the Voorhees article is whether the FTC and DOJ differed with respect to exclusionary conduct. I have analyzed the FTC's non-merger complaints for the three administrations. In addition to showing how FTC enforcement has changed, the FTC data also is useful for comparison to the DOJ. Bringing the FTC record into the mix permits some control for changes in the legal and economic climate over time. The preliminary results are listed below in Table $2 .^{48}$ The FTC complaints are listed in the Appendix at Table $5 .{ }^{49}$

\footnotetext{
${ }^{48}$ These results are preliminary because some further refinement is needed, particularly on the pre-1996 complaints. Republican Tim Muris became Chair in June 2001. Schering Plough was brought under Robert Pitofsky's Chairmanship in April 2001, and was counted as part of the Pitofsky Chairmanship, despite it being brought in Calendar 2001. During the Clinton administration, Republican Janet Steiger remained Chair until April 1995 when she was replaced by Democrat Robert Pitofsky. I have not yet adjusted the counts to reflect this. (There were 21 complaints in 1993-94 and 13 complaints in 1995. Of those 13, 4 were issued before Pitosfky took over. So, the total for Chairwoman Steiger is 25 and the total for Pitofsky is 46.) This reduces the Pitofsky complaints per year (because there were relatively more complaints brought in 1993 and 1994). But the basic conclusions would change because the most significant complaints were brought subsequently, including Dell, Intel, Mylan, Toys-R-Us and the pharma complaints. (In addition, I am mainly using the FTC data to compare the FTC and DOJ during the three administrations.)

${ }^{49}$ For this study, I began with a list of FTC complaints since 1996 posted by the Commission. See http://www.ftc.gov/bc/caselist/alphabetical/expanded/alphabetical.pdf. The complaints decided before 1996 are available at http://ftc.gov/os/decisions/index.shtm, but the list gives the decisions, not the dates of the complaints. This leaves a potential gap for pre-1996 matters that required further digging and the potential for
} 


\begin{tabular}{|c|c|c|c|c|c|}
\hline & $\begin{array}{c}\text { Clinton } \\
\text { (1993-2000) }\end{array}$ & $\begin{array}{l}\text { G.W. Bush } \\
\text { (2001-2008) }\end{array}$ & $\begin{array}{l}\text { G.W. Bush } \\
\text { (2005-2008) }\end{array}$ & $\begin{array}{l}\text { G.W. Bush } \\
\text { (2001-2004) }\end{array}$ & $\begin{array}{c}\text { Obama } \\
(2009-2012)\end{array}$ \\
\hline Collusive & 48 & 47 & 13 & 34 & 9 \\
\hline Exclusionary & 21 & 20 & 15 & 5 & 7 \\
\hline Both & 6 & 0 & 0 & 0 & 0 \\
\hline Total & 75 & 67 & 28 & 39 & 16 \\
\hline
\end{tabular}

Table 2

FTC Non-Merger Complaints: Summary Counts

The FTC is an independent, bipartisan agency with members whose terms overlap administrations. As Tim Muris has emphasized, the Chairman of the FTC has the power to set the agenda for non-merger investigations and complaints. ${ }^{50}$ But, as a bi-partisan, multi-member commission, there also are opportunities for logrolling. For both reasons, one would expect the FTC to be more tethered to the middle and subject to dampened swings, relative to the DOJ.

I begin by examining the FTC complaints over time. Comparing the FTC complaints under the Clinton and G.W. Bush administrations, there are significant similarities. First, the G.W. Bush FTC did not bring very significantly fewer complaints than the Clinton FTC. ${ }^{51}$ Second, the G.W. Bush FTC did not stop bringing exclusionary conduct complaints, though they did bring somewhat fewer than the Clinton FTC (i.e., 20 vs 27). The Bush administration FTC continued the Clinton's administration's program of cutting-edge exclusion complaints involving the pharmaceutical complaints that excluded generic

error. One judgment call involves whether to aggregate similar complaints brought on the same day but that are not part of the same complaint. I have preliminarily chosen to aggregate these, but will engage in further analysis, particularly on the pre-1996 complaints.

50 Panel Discussion: Politics \& Policy in 1981, James Cooper (ed.), THE REGULATORY REVOLUTION AT THE FTC: A THIRTY-YEAR PERSPECTIVE ON COMPETITION AND CONSUMER PROTECTION (2013)(forthcoming) at

${ }^{51}$ During the period of Steiger and Pitofsky leadership, the FTC brought 75 complaints, versus 67 under the G.W. Bush administration. (Note that the FTC was led by Republican Chair, Janet Steiger, until May 1995 and a significant number of the Clinton administration complaints were brought under her leadership.) 
pharmaceuticals. ${ }^{52}$ The Bush administration FTC also brought exclusion actions against Rambus, Unocal and N-Data for Kodak-like opportunistic behavior involving standard setting, complaints that followed the Dell complaint brought under FTC Chairman Pitofsky. Third, complaints against healthcare providers for collusive price setting were a high priority in both decades. Fourth, it appears that FTC Chairs, Deborah Majoras and William Kovacic, followed roughly the same agenda as Chairman Muris though with significantly fewer complaints. In 2001-2004, the FTC brought 39 complaints, versus 28 in the 2005-2008 period. $^{53}$

There also were some differences that show the power of the Chair to set the agenda. First, the Pitofsky (and Steiger) FTC brought a number of RPM complaints, whereas the Bush administration brought none. Second, the Muris FTC brought a significant number of state action complaints, which were not a priority for Pitofsky.

Comparing the other high visibility FTC complaints, I expect that Pitofsky would have supported the Polygram complaint brought by Chairman Muris. Chairman Muris suggested that he likely would not have brought the single firm exclusionary conduct complaint against Intel. ${ }^{54}$ He also likely would have supported the Toys-R-Us complaint in light of the evidence of horizontal communication among

\footnotetext{
${ }^{52}$ These included the complaints against Biovail, available at http://www.ftc.gov/os/2002/04/biovailcomplaint.htm; three related complaints against Bristol Myers Squibb, available at http://www.ftc.gov/os/2003/04/bristolmyerssquibbcmp.pdf; Cephelon, available at http://www2.ftc.gov/os/caselist/0610182/080213complaint.pdf; Warner Chillicott, available at http://www.ftc.gov/os/caselist/0410034/051107comp0410034\%20.pdf .

${ }^{53}$ It is noteworthy that the N-Data complaint was issued over the dissent of Chairwoman Majoras and future Chairman Kovacic. For the majority statement, see Statement of the Federal Trade Commission: In the Matter of Negotiated Data Solutions LLC, File No. 0510094, available at http://www.ftc.gov/os/caselist/0510094/080122statement.pdf. For Chairwomen Majoras' dissent, see Dissenting Statement of Chairman Majoras: In the Matter of Negotiated Data Solutions LLC, File No. 0510094http://www.ftc.gov/os/caselist/0510094/080122majoras.pdf. For Commissioner Kovacic's dissent, see Dissenting Statement of Commissioner William E. Kovacic: In the Matter of Negotiated Data Solutions LLC, File No. 0510094, available at http://www.ftc.gov/os/caselist/0510094/080122kovacic.pdf

${ }^{54}$ Personal communication. He lacked sufficient information from the Press Release to make a call about Mylan.
} 
the manufacturers. However, in the absence of this evidence, he was unlikely to have supported the case, whereas I expect that that Chairman Pitofsky would have.

Comparing the Bush and Obama FTC, the Obama FTC has brought fewer complaints - 16 in the first term versus 40 during the first term of G.W. Bush. The Obama FTC has brought 7 exclusionary conduct complaints during the first term versus 5 during the first Bush term. This small number of Obama FTC complaints raises the big question about why the caseload has declined. Comparing the types of complaints, the Obama administration has continued the program of bringing pharma exclusion complaints, despite a number of losses. Outside of pharma, the Obama administration brought high visibility exclusionary conduct complaints against Intel and Transitions that the Republicans would have been less likely to bring. ${ }^{55}$

I also compared the enforcement records of the FTC and the DOJ. Voorhees asks whether the FTC and DOJ differed from one another during the Bush administration. The Bush FTC brought many more complaints than did the Bush DOJ. A more refined analysis compares the change in the number of DOJ complaints to the change in the number of FTC complaints. The results of comparing Tables 1 and 2 in this way are summarized in Table 3, which reports the number of DOJ complaints of a particular type as a fraction of the number of FTC complaints in the same administration period.

\begin{tabular}{|c|c|c|c|c|c|}
\hline & $\begin{array}{c}\text { Clinton } \\
\text { (1993-2000) }\end{array}$ & $\begin{array}{l}\text { G.W. Bush } \\
\text { (2001-2008) }\end{array}$ & $\begin{array}{l}\text { G.W. Bush } \\
\text { (2005-2008) }\end{array}$ & $\begin{array}{l}\text { G.W. Bush } \\
\text { (2001-2004) }\end{array}$ & $\begin{array}{c}\text { Obama } \\
(2009-2012)\end{array}$ \\
\hline Collusive & $43 \%$ & $28 \%$ & $54 \%$ & $18 \%$ & $89 \%$ \\
\hline $\begin{array}{l}\text { Exclusionary } \\
\text { (Or Both) }\end{array}$ & $108 \%$ & $15 \%$ & $20 \%$ & $0 \%$ & $43 \%$ \\
\hline Total & $66 \%$ & $24 \%$ & $36 \%$ & $15 \%$ & $69 \%$ \\
\hline
\end{tabular}

\section{$\underline{\text { Table } 3}$}

55 The FTC's Google patent settlement in 2013 is not included in the sample. 


\section{DOJ Civil Non-Merger Complaints as a Percentage of FTC Complaints}

This comparison of differences in the ratios yields a number of interesting results about the lower enforcement levels at the Bush DOJ in comparison to the FTC, relative to the other administrations. First, referring back to Tables 1 and 2 as well as Table 3, the Clinton era DOJ brought about $64 \%$ of the number of complaints brought by the FTC (i.e., 48 vs 75 ), whereas the Bush era DOJ brought only $24 \%$ as many complaints as the FTC (i.e., 16 vs 67 ). Second, the Clinton DOJ brought $104 \%$ as many complaints that raised exclusion issues as did the FTC (i.e., 28 vs 27), whereas the Bush DOJ also brought $15 \%$ as many exclusionary conduct complaints (i.e., 3 vs 20). Third, the first-term Obama DOJ brought $69 \%$ as many complaints as did the FTC (i.e., 11 vs 16), whereas the first-term Bush DOJ brought

only $15 \%$ as many complaints as did the FTC (i.e., 6 vs 34). Fourth, with respect to exclusionary conduct complaints, the first-term Obama DOJ brought $43 \%$ as many complaints that raised exclusion concerns as did the FTC (i.e., 3 vs 7), whereas the first-term Bush DOJ brought no complaints while the FTC brought 5 . Fifth, the ratios for purely collusive conduct complaints are somewhat more similar between Clinton and Bush. The Clinton DOJ brought $42 \%$ as many as the FTC (i.e., 20 vs 48), whereas the Bush DOJ brought $28 \%$ as many collusive complaints as did the FTC (i.e., 13 vs 47 ). However, comparing the first terms of Obama and Bush, the differences are much larger. The first-term Obama DOJ brought $89 \%$ as many purely collusion complaints as the FTC (i.e., 8 vs 9), whereas the first-term Bush DOJ brought only $18 \%$ as many (i.e., 6 vs 34$)$.

Finally, another noteworthy difference between the Bush FTC and the Bush DOJ involves the pharma exclusion complaints. The Bush administration DOJ did not join the FTC in its petition for certiorari in Schering Plough. In contrast, the Obama DOJ recently has supported the FTC in seeking certiorari in the Watson case. The Obama DOJ also filed an Amicus brief in support of reconsideration 
of the legality of pay-for-delay payments at the Second Circuit in the Cipro case. ${ }^{56}$ In addition, the FTC

has shown aggressiveness by continuing to pursue this litigation agenda, despite several losses in court.

\section{E. Vertical Merger Enforcement}

Vertical mergers also raise exclusion concerns, so they are worth examining as well. There are significant differences between the G.W. Bush DOJ and the Democratic administrations that preceded and followed it. I have not done my own careful count but have relied on the work of others. Jeffrey Church lists 10 DOJ vertical merger enforcement actions during the Clinton administration. ${ }^{57}$ Church and Jonathan Jacobson have identified 15 vertical merger enforcement matters by the FTC during the Clinton administration. ${ }^{58}$ In contrast, I have identified only one clearly vertical merger action by the G.W. Bush DOJ, Northrop Grumman/TRW. ${ }^{59}$ There also were two DOJ horizontal merger enforcement actions that had vertical exclusion aspects, Masonite/Premdor ${ }^{60}$ and Monsanto/Delta and Pine. ${ }^{61}$ In my

56 For example, see Brief for the United States in Response to the Court's Invitation, In Re: Ciprofloxacin Hydrochloride Antitrust Litigation (July 6, 2009), available at http://www.justice.gov/atr/cases/f247700/247708.htm.

57 Jeffrey Church, Vertical Mergers, in 2 ISSUES IN COMPETITION LAW AND POLICY 1455 (ABA Section of Antitrust Law 2008). The DOJ matters are: United States v. Enova Corp., 107 F. Supp. 10 (D.D.C. 1999); United States v. USA Waste Servs., 1998-1 Trade Cas. (CCH) ๆ 72,171 (W.D. Pa. 1997); United States v. Allied Waste Indus., 1998-1 Trade Cas. (CCH) ๆ 72,156 (N.D. Tex. 1997); United States v. Thomson Corp., 1997-1 Trade Cas. (CCH) ๆ 71,754 (D.D.C. 1996); United States v. Sprint Corp., 1996-1 Trade Cas. (CCH)ף 71,300 (D.D.C. 1995); United States v. TeleCommc'ns, 1996-2 Trade Cas. (CCH) ๆ 71,496 (D.D.C. 1994); United States v. MCl Commc'ns, 1994-2 Trade Cas. (CCH) ๆ 70,730 (D.D.C. 1994); United States v. AT\&T Corp., 59 Fed. Reg. 44,158 (D.D.C. 1994); United States v. Lockheed Martin Corp., No. 98-CV-00731 (D.D.C. Mar. 23 1998) (verified complaint); United States V. MCl Commc'ns, 1994-2 Trade Cas. (CCH) ๆ 70,730 (D.D.C. 1994).

${ }^{58}$ Church's list include Shell Oil Co., 125 F.T.C. 769 (1998); Cadence Design Sys., 124 F.T.C. 131 (1997); Time Warner Inc., 12 F.T.C. 171 (1997), modified, 2004 WL 3118877 (FTC 2004); Silicon Graphics, 120 F.T.C. 928 (1995); Eli Lilly \& Co., 120 F.T.C. 243 (1995); Telecommunications, 119 F.T.C. 593 (1995); America Online, Inc., Docket No. C-3989 (FTC Apr. 17, 2001) (consent agreement), available at http://www.ftc.gov/os/2000/12/aolconsent.pdf; Dominion Resources, 128 F.T.C. 636 (1999); Hughes Danbury Optical Sys., 121 F.T.C. 495 (1996); Eli Lilly \& Co., 120 F.T.C. 243 (1995); TRW, Inc., 125 F.T.C. 496 (1998); Lockheed Corp., 119 F.T.C. 618 (1995); Alliant Techsystems Inc., 119 F.T.C. 440 (1995); Martin Marietta Corp., 117 F.T.C. 1039 (1994). The Barnes \& Noble/ Ingram proposed merger was abandoned in the face of FTC opposition. For a different discussion, see Jonathan Jacobson, ANTITRUST LAW DEVELOPMENTS (SIXTH) 383-386 (1997). Jacobson's list also includes the FTC's 1999 attack on Ceridian's acquisitions of NTS and Trendar, though the former acquisition was primarily horizontal (while the latter was vertical).

59 U.S. vs Northrop Grumman Corp. and TRW, Inc. (December 11, 2002), available at http://www.justice.gov/atr/cases/f200500/200555.htm.

60 U.S. v. Premdor, Inc., No. 1:01CV01696 (D.D.C. 2001). I consulted with the parties in this matter. 
view, both of these primarily concerned horizontal overlaps, though there were vertical issues as well. ${ }^{62}$

I so far have identified only one vertical merger action by the FTC during the G.W. Bush administration, Cytyc/Digene. ${ }^{63}$

The Obama DOJ in the first term has brought enforcement actions involving exclusionary effects from vertical mergers primarily in 4 matters, Comcast/NBCU, ${ }^{64}$ Live Nation/Ticketmaster, Google/ITA, ${ }^{65}$ and GrafTech/Seadrift Coke. ${ }^{66}$ While Live Nation/Ticketmaster had important vertical aspects, the the DOJ focused more on the horizontal issues. ${ }^{67}$ These Obama vertical merger complaints also involved the type of conduct remedies that often are criticized by conservative commentators. Thus, elections have seemed to matter with respect to exclusion issues in vertical merger complaints too. ${ }^{68}$

${ }^{61}$ United States v. Monsanto Co. (May 31, 2007), available at http://www.justice.gov/atr/cases/f223600/223677.htm. Monsanto's previous attempt to acquire Delta and Pine was abandoned in 1999 in the face of DOJ concerns. I consulted for an interested party in this matter.

${ }^{62}$ The Premdor/Masonite CIS also makes the argument that the merger would facilitate coordination by lowering the cost of the merged firm and thereby making it more similar to the other large vertically integrated firm. The claim that the greater symmetry would make merger-specific cost reductions anticompetitive would not seem to have reflected the views of the AAG at the time.

${ }^{63}$ FTC criticism led to the abandonment of the Cytyc/Digene merger in 2002. Press Release, Federal Trade Comm'n, FTC Seeks to Block Cytyc Corp.'s Acquisition of Digene Corp. (June 24, 2002), available at http://www.ftc.gov/opa/2002/06/cytyc_digene.shtm

64 U.S. et al v. Comcast Corp., General Electric Co, and NBC Universal Inc., (January 18, 2011), available at http://www.justice.gov/atr/cases/f266100/266164.htm

65 U.S. v Google, Inc. and ITA Software Inc. (April 8, 2011), available at http://www.justice.gov/atr/cases/f269600/269618.pdf I consulted with DOJ on this matter.

${ }^{66}$ U.S. v. GrafTech International Ltd. and Seadrift Coke L.P. (November 29, 2010), available at http://www.justice.gov/atr/cases/f264600/264606.htm.

${ }^{67}$ I have not yet done a careful count of Obama FTC vertical merger complaints. In 2010, there were vertical bottler acquisitions by both Coca Cola and Pepsi.

68 The issue of whether the DOJ during the Bush administration reduced horizontal merger enforcement has been well discussed in the literature and will not be repeated here. See Jonathan Baker and Carl Shapiro, supra note _; Jonathan B. Baker \& Carl Shapiro, Detecting and Reversing the Decline in Horizontal Merger Enforcement, ANTITRUST, Summer 2008, at 29. Timothy Muris... same issue, at page 37; John Harkrider same issue, at page 43; Jonathan M. Jacobson \& Sara C. Walsh, Merger Enforcement in an Obama Administration, 9 The Threshold 26 (Fall 2008); John D. Harkrider, Obama: The First Year ANTITRUST 8 (Summer 2010); D. Daniel Sokol, Antitrust, Institutions, and Merger Control, 17 GEO. MASON L.R. 1055 (2010); Daniel A. Crane, supra note 26 . For Baker and Shapiro's response, see Jonathan B. Baker \& Carl Shapiro, Response: Evaluating Merger Enforcement During The Obama Administration, 65 STAN. L. REV. ONLINE 28 (August 21, 2012), available at http://www.stanfordlawreview.org/sites/default/files/online/articles/Baker-Shapiro-65-SLRO-28.pdf. 


\section{F. Amicus Briefs}

Amicus briefs are another important way in which elections matter. Amicus briefs give an administration an antitrust forum to influence the courts. The agencies write numerous Amicus briefs each year, both to Circuit courts as well as the Supreme Court.

Leah Brannon and Douglas Ginsburg have reviewed the Amicus briefs of the Solicitor General (SG) to the Supreme Court for the period through 2007. Their review indicates the influence of the SG on the Court, in that the SG generally ends up on the winning side. ${ }^{69}$ The G.W. Bush administration supported defendants in almost every one of the large number of cases that came before the Court, including Trinko, ${ }^{70}$ Twombly, $^{71}$ linkLine, ${ }^{72}$ Dagher, ${ }^{73}$ Weyerhaeuser, ${ }^{74}$ and Leegin. ${ }^{75}$ In contrast, the Obama administration supported the plaintiffs in American Needle, as well as the FTC's Watson case. ${ }^{76}$ Watson is particularly significant in that the SG did not join the FTC in its petition in Schering Plough during the G.W. Bush administration. ${ }^{77}$

However, looking backwards in time, there is less difference. The Clinton administration supported the defendant in both Discon and Khan, which (along with the FTC's California Dental case)

69 The data in this section is taken from Leah Brannon and Douglas H. Ginsburg, Antitrust Decisions of the U.S. Supreme Court, 1967-2007, 3 COMPETITION POLICY INTERNATIONAL 3 (Autumn 2007).

70 Verizon Communications Inc., v. Trinko, 540 U.S. 398 (2004)

${ }^{71}$ Bell Atlantic Corp v. Twombly, 550 U.S. 544 (2007).

72 Pacific Bell Telephone Co. v. linkLine Communications, Inc., 555 U.S. _ (2009).

73 Texaco Inc. v. Dagher, 547 U.S. 1 (2006)

74 Weyerhaeuser Company v. Ross-Simmons Hardwood Lumber Company, 549 U.S. 312 (2007). I consulted with Weyerhaeuser on this matter.

${ }^{75}$ The exception is Credit Suisse Securities (USA) LLC v. Billing, where the DOJ and SEC had taken opposite positions at the Appeals Court and the Solicitor General recommended an intermediate (but pro-plaintiff) position to the Supreme Court.

76 Brief for the Petitioner, Federal Trade Commission v. Watson Pharmaceuticals, Inc., et al. (January 22, 2013), available at http://www.justice.gov/atr/cases/f291700/291720.pdf.

77 Surprisingly perhaps, the SG did not file a brief in the Comcast class action just decided by the Court in March 2013. In light of this case involving exclusionary conduct, one might have expected the Obama DOJ to become involved. 
were the main antitrust cases during that 8 year period. During the G.H.W. Bush and Reagan administrations, defendants were favored by the SG in the majority of the cases, but the SG notably supported the plaintiffs in Allied Tube and Hydrolevel, as well as NCAA and Maricopa. The SG notably did not take a position in Aspen Ski, Sharp or American Stores.

If there is a political effect operating here, the pure numbers conceivably might support a hypothesis that the Court has been less likely to accept antitrust cases during recent Democratic administrations. I have not studied this issue. But, if true, one possible explanation for this outcome could be the behavior of the DOJ itself. The DOJ and SG during Republican administrations have seemed aligned in their efforts to intervene in private cases where the plaintiffs prevailed below and they saw opportunities to reverse and thereby restrict doctrine in certain areas. It would seem likely that their briefs were influential in getting the Court to take those cases. In contrast, a Democratic DOJ rationally might have been less enthusiastic about urging certiorari when the defendants had prevailed below, out of fear that the relatively conservative Court would grant certiorari and make the law even more permissive. Of course, it would take more work to evaluate this issue rigorously.

\section{G. Agency Merger Guidelines}

Guidelines also serve as a forum to influence the courts. The 1982 Merger Guidelines were intended to loosen merger law as well as policy by giving more prominence to economics, and they clearly succeeded in doing so. ${ }^{78}$ The DOJ's 1984 Vertical Restraints Guidelines also were intended to reflect the conservative approach to vertical restraints and influence the courts to adopt a more permissive stance. The DOJ's Section 2 report had a similar goal, as discussed in more detail below.

\footnotetext{
${ }^{78}$ Two notable Circuit court opinions that cited the Merger Guidelines in finding against the government were United States v. Waste Mgmt., Inc., 743 F.2d 976 (2d Cir. 1984) and United States v. Baker Hughes, Inc., 908 F.2d 981 (D.C. Cir. 1990).
} 
The Obama administration issued new Horizontal Merger Guidelines in $2010 .^{79}$ These Guidelines raise the $\mathrm{HHI}$ thresholds. But they otherwise indicates a somewhat more pro-enforcement tilt, including a modernized critical loss methodology that leads to narrower markets, introduction of the parallel accommodating coordinated conduct theory that does not require detailed evidence of rapid detection and punishment, as well as greater suspicion of powerful buyers as a constraint on coordination. The Guidelines also now incorporate concerns regarding partial ownership interests and exclusionary effects. Some of these ideas were contained in the joint FTC/DOJ 2006 Merger Commentary, but they are given greater visibility and greater emphasis in the Merger Guidelines. ${ }^{80}$

The impact of ideology and politics can be illustrated by the treatment of unilateral effects in the Merger Guidelines. The 1982 and 1984 Merger Guidelines focused on what we now call coordinated effects concerns. For example, in his 1986 Hospital Corporation of America opinion, Judge Posner stated that "[w]hen an economic approach is taken in a section 7 case, the ultimate question is whether the challenged acquisition is likely to facilitate collusion." ${ }^{81}$ Unilateral effects had no role, despite the fact that there was a well-established economic analysis of non-collusive oligopoly conduct dating back 100 years - the famous Cournot and Bertrand equilibria. ${ }^{82}$ The only mention of what we would now call unilateral effects was in the so-called "leading firm proviso" that applied to firms with market shares in excess of $35 \%$. Product differentiation was viewed as a reason why coordination would be less likely to succeed, but not why there would be greater concerns about unilateral effects.

\footnotetext{
${ }^{79}$ Department of Justice and Federal Trade Commission, HORIZONTAL MERGER GUIDELINES (August 19, 2010), (hereinafter, 2010 Merger Guidelines) available at http://www.justice.gov/atr/public/guidelines/hmg-2010.html

${ }^{80}$ Federal Trade Commission and Department of Justice, COMMENTARY ON THE HORIZONTAL MERGER GUIDELINES (March 2006), available at http://www.ftc.gov/os/2006/03/CommentaryontheHorizontalMergerGuidelinesMarch2006.pdf. For a description that stresses the continuity with the Commentary, see Carl Shapiro, Update from the Antitrust Division (November 18, 2010), available at http://www.justice.gov/atr/public/speeches/264295.pdf.

${ }^{81}$ Hospital Corporation of America v. Federal Trade Commission, 807 F.2d 1381, _- ( $7^{\text {th }}$ Cir. 1986)

82 For a non-technical description, see William J. Kolasky, Coordinated Effects in Merger Review: From Dead Frenchmen to Beautiful Minds and Mavericks (Apr. 24, 2002), available at http://www.usdoj.gov/atr/public/speeches/11050.htm.
} 
The theory of unilateral effects from mergers first was included in the 1992 Merger Guidelines adopted when James Rill was AAG. ${ }^{83}$ It was given great emphasis by the economists involved in the drafting. ${ }^{84}$ However, there was an apparent concern that a full embrace of unilateral effects would lead to a significant increase in merger enforcement. This is because significant unilateral effects concerns can arise even if the combined market shares of the merging parties, and market concentration, are low. Indeed, the analysis of unilateral effects does not even strictly require markets to be defined. Apparently to avoid supporting over-enforcement, the 1992 Merger Guidelines added a sentence that could be read to suggest that unilateral effects theories would only be pursued if the combined market shares of the merging parties exceeded $35 \%$ and/or if the parties' products were uniquely closest substitutes, two caveats that do not follow directly from the economic analysis of unilateral effects.

The use of unilateral effects increased considerably during the Clinton administration. The use of sophisticated empirical data in the Staples case led to greater visibility for unilateral effects analysis. For example, Malcolm Coate and Shawn Ulrick report on a sample of 128 mergers evaluated by the FTC over the 1996-2003 period for which detailed data was collected on mergers that had second requests. ${ }^{85}$ The agency analysis appeared to focus on unilateral effects in about $70 \%$ of these mergers. In addition, unilateral effects theories were disproportionately likely to lead to enforcement actions. About $77 \%$ of the enforcement actions involved unilateral effects. ${ }^{86}$

\footnotetext{
${ }^{83}$ For one view of the history, see Jonathan B. Baker, Why Did the Agencies Embrace Unilateral Effects, 12 GEO. MASON L. REV. 31 (2003)

${ }^{84}$ Robert D. Willig, Merger Analysis, Industrial Organization Theory, and Merger Guidelines,1991 BROOKINGS PAPERS ON ECON ACTIVITY (MICROECONOMICS) 281;Janusz A. Ordover and Robert D. Willig, Economics and the 1992 Merger Guidelines: A Brief Survey, 8 REV. IND. ORG. 139 (1993).

${ }^{85}$ Malcolm B. Coate and Shawn W. Ulrick, Transparency at the Federal Trade Commission: The Horizontal Merger Review Process 1996-2003, 73 Antitrust L.J. 531 (2006). The fraction of unilateral effects challenges was somewhat smaller for a similar study over the 1989-2009 period. See Malcolm B. Coate, Bush, Clinton, Bush: Twenty Years of Merger Enforcement at the Federal Trade Commission, Competition Policy International (September 2009). Of course, all these comparisons are imperfect because the methodologies evolve over time and the number of deals of each type is not necessarily the same in each period. Moreover, Coate's data set includes only the FTC.

86 This figure includes merger to monopoly (i.e., 2-to-1) complaints.
} 
The change of administration in 2001 rekindled interest in coordinated effects theories at the DOJ. ${ }^{87}$ One reason for this was a concern about over-enforcement resulting from unilateral effects theories. This is because harms from unilateral effects do not necessarily require high market shares, or even market definition at all. ${ }^{88}$

Unilateral effects concerns take on a very prominent role in the 2010 Guidelines, including the more controversial, explicit use of upward pricing pressure indices. Over-enforcement concerns were raised in the comments of the ABA Antitrust Section, particularly the impact of high margins on market definition and unilateral effects analysis. ${ }^{89}$

Another possibly significant change involves the hypothetical monopolist test methodology for relevant product market definition for markets with differentiated products. The 2010 Merger Guidelines use a newer critical loss methodology that incorporates into the analysis the information about demand substitution revealed by the margin of a profit-maximizing firm. ${ }^{90}$ This methodology leads to systematically narrower markets. For example, the Guidelines provide an example of a market satisfying the hypothetical monopolist test where two-thirds of the customers lost by a firm that raises

87 For some contemporaneous commentary, see Charles A. James, Rediscovering Coordinated Effects (Aug. 13, 2002), available at http://www.usdoj.gov/atr/public/speeches/200124.htm. See also William J. Kolasky, Coordinated Effects in Merger Review: From Dead Frenchmen to Beautiful Minds and Mavericks (Apr. 24, 2002), available at http://www.usdoj.gov/atr/public/speeches/11050.htm; Jonathan B. Baker, Why Did the Agencies Embrace Unilateral Effects, 12 GEO. MASON L. REV. 31 (2003); Stuart D. Gurrea \& Bruce M. Owen, Coordinated Interaction and Clayton $\& 7$ Enforcement, 12 GEO. MASON L. REV. 89 (2003).

88 As AAG Charles James colorfully put it, "if placed under sodium pentathol, most economists would concede that market definition is not particularly important in unilateral effects analysis, an additional fact that can make it difficult to square the case theory with the way many courts tend to view merger issues." Charles A. James, Rediscovering Coordinated Effects (August 13, 2002), available at http://www.justice.gov/atr/public/speeches/200124.htm.

89 For example, see Comments of the ABA Antitrust Section of Antitrust Law Regarding the Federal Trade Commission and Department of Justice Horizontal Merger Review Project No. P092900 (November 9, 2009).

902010 Merger Guidelines at §4.1.3. 
price substitute to firms outside the relevant market. ${ }^{91}$ Of course, it remains to be seen the extent to which this test will be used by the agencies and whether it will be accepted by the courts.

\section{H. The 2001 Microsoft Settlement}

The Voorhees article specifically asks about the Microsoft settlement and how it was affected by the 2000 election. This is relevant to the discussion of exclusionary conduct because it is the most important Section 2 complaint to be brought in a generation. In my view, the Microsoft case is a very good example of how elections matter. ${ }^{92}$

The case obviously was highly visible and politically sensitive from the very beginning. While still a Presidential candidate, George W. Bush expressed great reservations about the Microsoft case and the break-up remedy. Speaking at a campaign event in the state of Washington, 15 miles from Redmond, he is quoted as saying that "he was 'worried' about the consequences 'if this company were to be broken apart, this engine of change, engine of growth ... [B]ut we'll see what the courts say on the issue.'"193 Several days later, Mr. Bush discussed the proposed breakup remedy in even clearer negative terms. A Bloomberg report in USA Today entitled, "Bush Opposes Microsoft Breakup" states, "Asked before a campaign event Friday on Long Island whether Redmond, Wash.-based Microsoft should be broken up, Bush said, 'I'm against it. There has got to be a better remedy than to break up a successful company that employs lots of people." 94

It is certainly reasonable to expect that this statement would have had salience for the DOJ Transition team and the people he appointed to lead the Justice Department. In fact, two members of the Transition team were Rick Rule and Charles James. As noted earlier, Rick Rule was one of

\footnotetext{
${ }^{91}$ Id. at $§ 4.1 .1$ (Example 5).

92 I consulted with clients on the anti-Microsoft side on the case and the settlement.

93 Mike Allen, Bush Hints He Would Not Have Prosecuted Microsoft, Washington Post (Feb 28, 2000), available at http://www.washingtonpost.com/wp-srv/pmextra/feb00/28/A43853-2000Feb28.html.

94 Bloomberg, Bush Opposes Microsoft Breakup (March 3, 2000), available at http://usatoday30.usatoday.com/news/e98/e1296.htm.
} 
Microsoft's attorneys and Charles James was then appointed to be the Antitrust AAG in 2001.

Moreover, Rule was one of the lead negotiators for the Microsoft settlement and Charles James was the AAG who agreed to the settlement.

The Voorhees article suggests that the weakness of the settlement was mainly the result of a weak court of appeals decision. In my view, the decision was not weak at all. It affirmed the primary Section 2 monopolization count and adopted a Section 1-style rule of reason balancing standard in the process. ${ }^{95}$ It did remand the tying count. The District rejected the Section 1 exclusive dealing count, which was not appealed, the D.C. Circuit stated its disagreement with the standard used by the District Court. The D.C. Circuit also affirmed the illegality of Microsoft's exclusive dealing under Section 2. To make a criminal law analogy, it is as if the defendant was found guilty of kidnapping murder, but the jury hung on the assault count. The DC Circuit did express reservations about the break-up remedy, so it certainly could be argued that a Democratic administration also might have abandoned that remedy. But, even the conduct constraints placed on Microsoft's behavior by the settlement were weak, including provisions that said little more than Microsoft should not "unreasonably" exclude. The settlement also did not prohibit the commingling browser and operating system code, despite the fact that this conduct was explicitly held to be anticompetitive in the D.C. Circuit opinion. ${ }^{96}$ At the time, I characterized the settlement as "catch and release" antitrust enforcement. Microsoft still retains its monopoly in desktop operating systems, though it has not been able to leverage this monopoly into Internet search or mobile operating systems. ${ }^{97}$

\section{J. The DOJ's Section 2 Report}

95 U.S. v. Microsoft Corp., 253 F.3d 34 (D.C. Cir. 2001)

${ }^{96}$ United States v. Microsoft Corporation 253 F.3d 34, 66 (D.C. Cir. 2001)

97 The DOJ consent decree did not prohibit Microsoft from tying Internet Explorer to Windows, or using Windows to give Internet Explorer a distributional advantage over other browsers. Nor did it prevent Microsoft from bundling its search engine with Windows or Internet Explorer (as, indeed, it did during the pendency of the decree, and continues to do to this day). 
The Voorhees article also raises the issue of the DOJ's Section 2 report issued in 2008 and its subsequent withdrawal in 2009. I think this episode is consistent with the interaction of politics, ideology and elections. The primary purpose of the Section 2 report did not seem to be a statement of the DOJ's enforcement intentions. ${ }^{98}$ The report was issued two months before the 2008 election, seven years into the Bush administration. It was already quite clear that the Division was unlikely to bring any Section 2 complaints or many exclusionary conduct complaints under Section 1 . Instead, the likely audience of the report was the courts and its likely message was that the courts should take a very permissive approach to exclusionary conduct.

Nor did the report provide a consensus view of Section 2 law. The FTC dissented from its conclusions. The report also reached more conservative conclusions that did the Antitrust Modernization Commission. Thus, AAG Varney's withdrawal of the report in 2009 was no surprise. It was an obvious tit-for-tat response to the issuance of the report and served as a clear signal to the courts about the lack of consensus.

Withdrawing the report also was necessary if the administration were to have any interest in litigating exclusionary conduct cases. Herbert Hovenkamp has stated this point very well.

As soon as President Obama was elected, withdrawal of the Section 2 Report was virtually a foregone conclusion. The Report was extremely tolerant of single-firm conduct, making it extraordinarily difficult to prove a violation in many areas, particularly those involving pricing and refusals to deal. If President Obama's antitrust enforcers were to act consistently with his own campaign positions, they very likely would have ended up litigating against their own Report. Bitter experience with an earlier version of the Justice Department's Merger Guidelines demonstrated that business firms are entitled to rely on antitrust guidelines. As a result, the Division could not state a position declaring one standard and later bring an action seeking to establish a standard that is harsher on defendants. Thus, the Obama Antitrust Division's hand was forced: unless the Division withdrew the Report, the Division would continue to be noosed in by it. ${ }^{99}$

\footnotetext{
98 United States Department of Justice, Competition and Monopoly: Single-Firm Conduct Under Section 2 of the Sherman Act ( September 2008), available at http://www.justice.gov/atr/public/reports/236681.pdf

${ }^{99}$ Herbert Hovenkamp, The Obama Administration and Section 2 of the Sherman Act, 90 BOSTON U.L.R. 1611,1613 (2010).
} 
Finally I think that there is also an ideological interpretation. The Section 2 report likely represented a statement of AAG Barnett's ideology regarding the proper enforcement of Section 2. The withdrawal of the report by AAG Varney thus similarly was a statement that the Obama DOJ did not share the antitrust ideology of the previous administration, even aside from the other motives discussed above. ${ }^{100}$

Based on all this evidence, it certain appears that elections and ideology have mattered with respect to DOJ enforcement. But, the DOJ under G.W. Bush brought fewer civil non-merger complaints, relative to the Clinton DOJ and the Obama DOJ during its firm term. The G.W. Bush DOJ had less focus on exclusionary conduct enforcement, both with respect to civil non-merger complaints and vertical merger cases. (I did not study horizontal mergers.) Even aside from the numbers, its enforcement record showed a disinclination to take on large national firms or go to court. The same conclusions follow from a comparison of the DOJ to the FTC during the G.W. Bush administration. The DOJ brought relatively fewer cases, and relatively fewer exclusionary conduct complaints, although the FTC also was not active in vertical merger enforcement.

In the policy realm, the G.W. Bush also expressed its distaste for exclusionary conduct enforcement with the Microsoft settlement in 2001 and Section 2 report in 2008 serving as book ends to a period of minimal enforcement. At the Supreme Court, it sided regularly with defendants' attempt to limit class action litigation, particularly with respect to Section 2 . It also did not support the FTC in its pharma exclusionary conduct case.

100 In this interpretation, the FTC statement represented opposition to the ideology, not just the DOJ's enforcement plans. After all, as an independent agency that is given deference by the courts and with a different statute, the FTC may well not share the DOJ's enforcement agenda. 
The Obama DOJ has reversed direction. It withdrew the Section 2 report and has issued more enforcement-oriented Merger Guidelines. It has taken aggressive action towards MFNs and has been willing to take large cases to court, including mergers. At the same, it has not so far generated the degree of change that some expected. Of course, a DOJ generally blossoms in the second term of the administration. So, the Obama DOJ must still be treated as a work in progress.

\section{Political Pressure}

Voorhees also raised the issue of political pressure on the agencies and the courts. It is clear that politicians can have an effect on the courts and the agencies through the appointment process. But, this does not mean that they often try to place pressure in specific matters and if they succeed when they do. The successful application of such pressure does appear rare but it also is hard for outsiders to detect. There are some clear examples of pressure being inflicted and affecting antitrust law and policy in important ways.

\section{A. Political Pressure on the Supreme Court: the Case of Vertical Price Agreements}

It seems obvious that the political climate or partisan politics animates the Supreme Court. In antitrust, one classic example is Appalachian Coals, which interrupted the clear trend of Section 1 doctrine. Perhaps the clearest and most important modern example of politics affecting antitrust doctrine is Sylvania and its progeny.

Sylvania was decided in the context of longstanding political developments involving vertical price restraints. The Sylvania opinion notes the fact that Congress had recently approved the per se rule against vertical price fixing by repealing the Miller-Tydings and McGuire Acts. ${ }^{101}$ But, the Monsanto story is even more interesting. ${ }^{102}$ The DOJ wrote an Amicus brief supporting reversal of Dr. Miles. In

\footnotetext{
${ }^{101}$ Continental T.V., Inc. v. GTE Sylvania Inc., 433 U.S. 36 (1977) at n.18

102 Monsanto Co. v. Spray-Rite Serv. Corp., 465 U.S. 752 (1984)
} 
response, Congress passed a bill denying the DOJ funding to argue the case at the Supreme Court. AAG Baxter noticeably attended the oral argument but did not argue. Andrew Gavil's study of the Powell and Marshall papers makes it clear that Justice Powell did not attempt to overrule Dr. Miles in Monsanto in light of these apparent Congressional attitudes. ${ }^{103}$ In his file memo, Justice Powell noted that Congress had prohibited the Justice Department from participating in the Monsanto oral argument. This seems like a clear example of political pressure having a potentially very significant on the Supreme Court.

But, perhaps the most interesting part of story is the way in which the Supreme Court dealt with this pressure. Although it found for the plaintiff in Monsanto and did not reverse Dr. Miles, the Court in its opinion tightened the legal standards governing the agreement requirement and thereby restricted the scope of Dr. Miles' per se rule. In both Monsanto and Sharp, the Court made it more difficult for plaintiffs to prove the existence of a vertical price fixing agreement to which the per se rule would then be applied. In Monsanto, the Court held that it was insufficient for the plaintiff merely to establish that termination of a dealer followed the complaints of a rival. In Sharp, the Court held that it was necessary to show an agreement about a specific price, rather than just a price range. Moreover, the Court was quite explicit that the goal of this doctrinal tactic was to restrict the continued impact of Dr. Miles in order to protect the rule of reason standard set out in Sylvania.

Thus, the interesting question is thus how best to interpret this story of political pressure. One interpretation is that the Supreme Court successfully resisted political pressure from Congress and loosened the law of vertical price restraints. But, another interpretation is quite different. This interpretation is that the Court evaded the political pressure only by manipulating and distorting the antitrust doctrine of agreement. ${ }^{104}$ They accounted for potential efficiencies from vertical price

103 Andrew I. Gavil, Sylvania and the Process of Change in the Supreme Court, 17 ANTITRUST 8 (Fall 2002).

104 For a general discussion of the ways in which changes in substantive and procedural standards might be related, see Stephen Calkins, Summary Judgment, Motions to Dismiss, and Other Examples of Equilibrating Tendencies in the Antitrust System, 74 GEO. L.J. 1065 (1986). 
restraints by making it more difficult to prove a price agreement. But, this tactic significantly affected the antitrust doctrine of the agreement requirement beyond RPM. The Court also made it harder to prove horizontal price fixing agreements. This has had a significant impact on horizontal collusion cases, such as the Eighth Circuit's opinion in Blomkest. ${ }^{105}$ Since horizontal price fixing often is called the worst antitrust offense, one would have to wonder if the Court struck the best trade off here, or whether it threw out part of the baby with the bath water. ${ }^{106}$

Moreover, the harm from this doctrinal tactic survives to this day. Even though Leegin has now finally reversed Dr. Miles, the Court has not adjusted the doctrine to undo their self-confessed manipulation of the agreement requirement in Monsanto and Sharp. Thus, in the end, the Congressional pressure on the court in Monsanto ended up having very significant effects on antitrust law, albeit likely not what was intended by the application of the pressure. Thus, while this is only a single anecdote, it certainly is one that has been highly significant.

\section{B. Pressure on the Agencies in Specific Cases}

There is also the easier question of whether and how Congress and the President affect particular antitrust actions by the agencies, as opposed to antitrust policy generally. We have the famous examples of President Nixon attempting to stop the ITT case in exchange for campaign contributions and President Johnson promising to get the DOJ to permit a newspaper merger in exchange for political support. I mentioned earlier the example of President's Reagan's intervention in the Financial Interest and Syndication rules and support for the Microsoft case by Senators Hatch and Metzenbaum. But, there is an issue of how often pressure is applied and, more importantly, how often it actually succeeds in affecting the outcome.

\footnotetext{
${ }^{105}$ Blomkest Fertilizer, Inc. v. Potash Corp. of Saskatchewan, Inc., 205 F.3d. 1028 (2000).

${ }^{106}$ While collusion may be the worse offense, exclusion may be considered the more fundamental conceptual concern in that some type of barriers to entry and expansion is necessary for durable collusion. See Jonathan B. Baker, Exclusion as a Core Competition Concern, 78 ANTITRUST L.J. 901 (2013).
} 
This is more a question for ex-AAGs and ex-Chairs of the FTC. An outsider faces difficult issues regarding detection of the pressure or the responses by the agencies. ${ }^{107}$ First, the subtle effect of the AAG or FTC simply wanting to remain in the good graces of the powerful, whether it is the Congressional committee or the President, is undetectable. ${ }^{108}$ The recollection of the FTC being called out by the Washington Post as the "National Nanny" remains vivid in the collective institutional memory of the antitrust agencies. It does not take a rocket scientist to know that bringing a complaint against a large campaign donor may generate issues for the recipients of the contributions. Second, the fact that observations of political pressure are limited to public statements means that the incidence of political pressure is understated. The most effective pressure does not require public pronouncements, but may involve secret threats or promises. Third, the AAG or FTC Chair who succumbs to the pressure likely would have a strong incentive to keep it secret to avoid being tarred as someone who can be controlled. So, we should not expect to detect many instances of such successful public pressure, even if it occurs. Thus, this issue is a job for real historians, not armchair ones.

One very public episode of Presidential pressure was the LTV-Republic steel merger in $1984 .{ }^{109}$ The parties apparently discussed the merger with the White House in advance of announcing it. One

107 My comments on some of these issues are subject to an important caveat. I am an economist, not an historian or a political scientist, and the empirical evidence on many of these issues is weak or non-existent. However, I nonetheless hope that this discussion throws some light on the issues he raises and suggests some topics for further study.

108 Making waves and creating political problems can affect the AAG's or FTC Chair's future political job prospects or damage one's political party.

${ }^{109}$ For a sampling of contemporary news reports, See Leslie M. Werner, "Steel Decision Called No Surprise," New York Times (February 27, 1984), available at http://www.nytimes.com/1984/02/17/business/steel-decision-calledno-surprise.html?n=Top\%2fReference\%2fTimes\%20Topics\%2fSubjects\%2ff\%2fFinances; New York Times, "Optimism on Steel Tie," (February 27, 1984), available at http://www.nytimes.com/1984/02/27/business/optimism-on-steeltie.html?n=Top/Reference/Times\%20Topics/Subjects/F/Finances; Kenneth Noble, "Antitrust Pact Seen on Steel," New York Times (March 17, 1984), available at http://articles.mcall.com/1984-03-14/business/2401684_1_sheetsteel-steel-plants-second-largest-steel-producer; Robert Hershey, jr., "Approval is Given to Amended Plan for Steel Merger," New York Times (March 21, 1984), available at http://www.nytimes.com/1984/03/22/business/approval-is-given-to-amended-plan-for-steelmerger.html?n=Top\%2fReference\%2fTimes\%20Topics\%2fSubjects\%2fF\%2fFinances; "Steel Merger Go Ahead," 
key, claimed defense of the merger was the constraining influence of steel imports. The DOJ was skeptical of the import claims and blocked the initial proposal. (The joke at the time was that in the morning, the companies explained to the Antitrust Division that foreign competition would prevent price increases, while in the afternoon, they lobbied Congress for import quotas.)

President Reagan and his Secretary of Commerce, Malcolm Baldrige, both criticized the DOJ's decision. President Reagan was quoted as saying, "'I realize that this is a judicial matter, but I don't mind saying that I don't believe the merger would reduce competition in the steel industry." ${ }^{110}$ Secretary Baldrige called it a "world class mistake." ${ }^{111}$ The Attorney General publically defended the Antitrust Division. In the end, Republic divested two plants and the merger was permitted. I have been told by Deborah Garza, who was a special assistant to AAG McGrath, that in light of a lack of direct communication from the White House, the DOJ made the decision solely on the basis of the antitrust facts. ${ }^{112}$ In this sense, the politicians were merely making empty political statements for public consumption.

Of course, what is possible - and undetectable - is that the pressure made a difference in subsequent complaints brought by subsequent AAGs. For example, even if the congressional pressure was not the cause of the termination of the FTC's Children's Television Advertising (Kid-Vid) rulemaking, if the rulemaking died of its own accord, the impact of the "national nanny" label surely affected later FTC activities. The same effects could occur from political pressure.

Pittsburgh Press (March 26, 1984), available at http://news.google.com/newspapers?nid=1144\&dat=19840326\&id=bOEbAAAAIBAJ\&sjid=VGIEAAAAIBAJ\&pg=618 0,6333992

${ }^{110}$ New York Times, Steel Merger and Reagan, (March 8, 1984), available at http://www.nytimes.com/1984/03/08/business/steel-merger-reagan-president-reagan-said-yesterday-that-hedid-not-believe-that.html

${ }^{111}$ Thomas E. Kauper, The Legacy of LTV/Republic Steel, 68 ANTITRUST L.J. 753, 754 (2001)

${ }^{112}$ Personal communication. 
The steel story is just a single anecdote and the ultimate effect of the lobbying is not clear. There have been statistical studies that attempted to quantify the impact of political pressure on FTC merger enforcement during the Reagan administration. FTC economist Malcolm Coate and his coauthors analyzed the statistical influence of Congressional Hearings on FTC merger outcomes during the Reagan administration. They found that generalized Congressional pressure significantly increased the likelihood of merger challenges during that period, though they do not identify specific cases that were affected. ${ }^{113}$ In a separate statistical analysis of political control over the 1993-2000 period, Coate concludes that the President is able to set the agenda for merger control, subject to certain bounds set by the composition of the Congress. However, the interaction is quite complex. ${ }^{114}$ And, it is not clear that it applied to specific cases, rather than enforcement trends generally.

The LTV/Republic matter is not unique. There have been many more recent examples of attempted political pressure, including AT\&T in its attempted merger with T-Mobile and both sides in the FTC investigation of Google, among others. I expect that antitrust lawyers and economists generally believe that these tactics are virtually never unsuccessful. But, if so, this raises the question of why otherwise rational profit-maximizing firms would spend considerable sums of money on unsuccessful public relations firms. Economists have a simple answer to this question - Prisoner's Dilemma. The opposing firms may be stuck at a lose-lose Nash equilibrium where both sides are making large expenditures that essentially cancel out one another. Yet, if either side foregoes the spending, the other side will prevail.

\section{Conclusions}

All in all, there is evidence that ideology and politics have a continued impact on antitrust law and agency enforcement. Antitrust has not become a purely technocratic exercise where all the participants

\footnotetext{
${ }^{113}$ Malcolm B. Coate et. al., Bureaucracy and Politics in FTC Merger Challenges, 33 J. L. ECON. 463,465 (1990). A possible criticism of the article is the assumption that the hearings were not caused by real anticompetitive concerns. If they were, then the regression results might be biased.

${ }^{114}$ Malcolm B. Coate, A Test of Political Control of the Bureaucracy: The Case of Mergers, 14 ECON\& POLITICS 1 (2002).
} 
agree on the goals and the proper standards. While every AAG and FTC Chair can be said to be acting like an umpire calling balls and strikes, they differ in their strike zones in systematic ways. 


\section{APPENDIX TABLES}


Table 4

DOJ Civil Non-Merger Complaints: $1993-2012^{115}$

Collusive/ Exclusionary Section 1 or 2

$\underline{1993}$

[Canstar Sports USA, Inc].

(not counted in totals) ${ }^{116}$

Collusive (RPM)

1994

Microsoft Corp.

Exclusionary

$1 \& 2$

Topa Equities

Exclusionary

1

Assoc. of Retail Travel Agents

Collusive

1

Delta Dental of Arizona

Exclusionary (MFN)

1

Vision Service Plan

Pilkington PIc.

Exclusionary (MFN)

1

Nagel Motors, Inc. et. al

Exclusionary

$1 \& 2$

S.C. Johnson/ Bayer, Inc.

Collusive

California SunCare, Inc.

Collusive/Exclusionary

Collusive (RPM)

1

Electronic Payment Services, Inc.

Utah Soc. for Healthcare Human Resources Admin.

Exclusionary (Tying)

1

Alliant Techsystems Inc./ Aerojet-General

Collusive

Collusive/Exclusionary

$\underline{1995}$

Health Choice of Northwest Missouri, Inc.

Exclusionary
Collusive/Exclusionary
Collusive/Exclusionary
Exclusionary
Collusive/Exclusionary
Exclusionary (MFN)
Collusive (RPM)
Collusive

National Auto. Dealers Assoc.

American Bar Assoc.

Greyhound Lines, Inc.

HealthCare Partners, Inc.

Lykes Bros. Steamship Co., Inc.

Playmobil USA, Inc.

NASDAQ

$\begin{array}{lc}\text { Exclusionary } & 1 \& 2 \\ \text { Exclusionary (tying) } & 1 \& 2 \\ \text { Exclusionary (MFN) } & 1 \\ \text { Collusive/Exclusionary } & 1 \\ \text { Collusive } & 1 \\ \text { Exclusionary (MFN) } & 1 \\ & \\ \text { or the Clinton DOJ. The Consent Decree is dated } \\ \text { ed until April 29, 1993. }\end{array}$

1996

General Elec. Co.

City of Stilwell

Delta Dental of Rhode Island

American National Can Co./ KMK Mashinen

Brush Fibers, Inc./ A \& L Mayer Associates, Inc.

Universal Shippers Assoc., Inc.

${ }^{115}$ Complaints are listed by Calendar Year, not Fiscal Year.

${ }^{116}$ The 1993 Canstar Sports USA case is not included in the totals for the Clinton DOJ. The Consent Decree is dated March 17, 1993 and AAG Ann Bingaman was not officially nominated until April 29, 1993. 
AnchorShade, Inc.

Women's Hosp. Foundation

Assoc. of Family Practice Residency Directors

Waste Management of Georgia, Inc.

Browning - Ferris Industries of lowa, Inc.

Texas Television, Inc.

Scuba Retailers Assoc.

1997

Seminole Fertilizer Corp.

IBM/Storage Technology

$\underline{1998}$

Visa U.S.A., Inc./ MasterCard

Federation of Physicians Dentists, Inc.

Microsoft Corp.

Mercury PCS II, L.L.C.

Medical Mut. of Ohio

\section{9}

Dentsply Intern., Inc.

AMR Corp.

Federation of Certified Surgeons and Specialists, Inc.

Citadel-Triathlon JSA

\section{$\underline{2000}$}

American Society of Composers, Authors, and Publishers American Stock Exchange/CBOE/Pacific Exchange/Phila.

Exchange

Citadel/Capstar

FCSSI

$\begin{array}{cc}\text { Collusive (RPM) } & 1 \\ \text { Exclusionary (MFN) } & 1 \& 2 \\ \text { Collusive } & 1 \\ \text { Exclusionary } & 2 \\ \text { Exclusionary } & 2 \\ \text { Collusive } & 1 \\ \text { Collusive } & 1\end{array}$

$\begin{array}{cc}\text { Collusive } & 1 \\ \text { Collusive/Exclusionary } & 1\end{array}$

$\begin{array}{cc}\text { Exclusionary } & 1 \\ \text { Collusive } & 1 \\ \text { Exclusionary } & 1 \& 2 \\ \text { Collusive } & 1 \\ \text { Exclusionary (MFN) } & 1\end{array}$

$\begin{array}{cc}\text { Exclusionary } & 1 \& 2 \\ \text { Exclusionary } & 2 \\ \text { Collusive } & 1 \\ \text { Collusive } & 1\end{array}$

Collusive $\quad 1$

Collusive 1

Collusive 1

Collusive 1

\section{$\underline{2001}$}

None

\section{$\underline{2002}$}

Mountain Health Care, P.A.

Collusive 1

Math Works/ Wind River Systems

Collusive

1

Nat'I Assoc. of Police Equipment Distributors, Inc.

Collusive

\section{$\underline{2003}$}

Nat'I Council on Problem Gambling, Inc.

Collusive

Village Voice Media, LLC

Collusive 


\section{$\underline{2005}$}

National Assoc. of Realtors

Exclusionary 1

Federation of Physicians and Dentists

Collusive 1

Ecast/ NSM Music Group

Collusive 1

Professional Consultant Insurance Co.

Collusive

Bluefield Regional Med Center/ Princeton Comm. Hosp.

Assoc.

Collusive

1

Kentucky Real Estate Commission

Collusive

$\underline{2006}$

None

$\underline{2007}$

Daily Gazette Co./ MediaNews Group

Collusive

$1 \& 2$

Hilton Head MLS

Arizona Hospital and Healthcare Assoc

Exclusionary

\section{8}

Consolidated Multiple Listing Service, Inc.

Exclusionary

None

\section{$\underline{2010}$}

American Express/Visa/MasterCard ${ }^{117}$

Collusive

1

Michigan BCBS

Lucasfilm/Adobe/Apple, Google/Intel/Intuit/Pixar ${ }^{118}$

Keyspan Corp./Morgan Stanley ${ }^{119}$

Exclusionary (MFN)

1

Collusive

Idaho Orthopaedic Society

Collusive

1

Collusive

\section{1}

\footnotetext{
${ }^{117}$ These are counted as a single matter in the counts.

${ }^{118}$ These are counted as a single matter in the counts.

${ }^{119}$ The Morgan Stanley settlement occurred in 2011.
} 
2012

Gunnison Energy/SG Interests I, Ltd.

Apple/Book Publishers ${ }^{120}$

eBay

Twin America ${ }^{121}$
Collusive

Collusive/Exclusionary

Collusive

Collusive
1

1

1

1

${ }^{120}$ This is counted as a single matter.

${ }^{121}$ This was similar to a merger, but was strictly a joint venture. A complaint was issued. 
Draft: April 5, 2013

Table 5

FTC Non-Merger Complaints: 1993-2012

\section{2}

IDEXX Laboratories, Inc.

Exclusionary

Coopharma Pharmacy - Farmacia Cuquimar

Collusive

McWane/Sigma/Star

Collusive

\section{1}

Pool Corp.

Exclusionary

Southwest Health Alliances, Inc.

Collusive

2010

Minnesota Rural Health Cooperatives

Collusive

Amerco / Avis Budget Group

Collusive

Transitions Optical, Inc

Exclusionary

Boulder Valley IPA (M. Catherine Higgins)

Collusive

Roaring Fork Valley Physicians, IPA, Inc.

Collusive

North Carolina Dental Board

Exclusionary

\section{$\underline{2009}$}

Alta Bates Medical Group

Collusive

MAP Policies of Musical Instrument Mfg

Collusive

West Penn MLS

Exclusionary

Watson Unimed

Exclusionary

Intel Corporation

Exclusionary

\section{8}

AllCare IPA

Collusive

Boulder Valley IPA

Collusive

Golf Galaxy (Dick's Sporting Goods)

Exclusionary

Connecticut Chiropractic Association /Congress of Chiropractic

Council

Collusive

Negotiated Data Solutions, LLC ${ }^{122}$

Exclusionary

Cephalon, Inc.

Exclusionary

\section{7}

\footnotetext{
${ }^{122}$ I have classified these "opportunism" or "hold-up" cases as exclusionary because the opportunism is often used against competitors, as in the case of Unocal. But, the opportunism could involve a standalone patent holder as in this matter.
} 
Multiple Listing Service, Inc.

Colegio de Optometras de Puerto Rico

Motor Oil Importers of Puerto Rico

Missouri State Board of Embalmers \& Funeral Directors
Exclusionary

Collusive

Exclusionary

Exclusionary

Collusive

Exclusionary

Exclusionary

Exclusionary

Exclusionary

Exclusionary

Collusive

Collusive

Exclusionary

Collusive

Collusive

Exclusionary

Exclusionary

Collusive

Collusive

Collusive

Collusive

Exclusionary

\section{$\underline{2004}$}

White Sands Health Care System, LLC Collusive

Clark County Attorneys

Collusive

Southeastern New Mexico Physicians, IPA

Collusive

Alpharma Inc.

Collusive

\section{$\underline{2003}$}

Tenet Healthcare Corporation and Frye Regional Medical Center, Inc

Collusive

Memorial Hermann Health Network

Collusive

New Hampshire Motor Transport Association

Collusive

South GA Health Partners (SGHP)

Collusive

Surgical Specialists of Yakima

Collusive

${ }^{123}$ These non-compete agreements are treated as exclusionary. 
The lowa Movers and Warehouseman's Assn

Collusive

Minnesota Transport Services Association

Collusive

Physician Networks Consulting

Collusive

Maine Health Alliance

Collusive

Washington University Physician Network

Collusive

Southwest Physician Associates

Collusive

Anesthesia Service Medical Gro

Collusive

Carlsbad Physician Association

Collusive

The Institute of Store Planner

Collusive

Indiana Household Movers and Warehousemen

Collusive

BMS (Buspar; Cisplatin; Taxol) ${ }^{124}$

Exclusionary

Piedmont Health Alliance

Collusive

North Texas Specialty Physicians

Collusive

South Carolina State Board of Dentistry

Exclusionary

Movers Conference of Mississippi

Collusive

Alabama Trucking Association

Collusive

Kentucky Household Goods Carriers Association, Inc.

Collusive

California Pacific Medical Group

Collusive

Union Oil of California

Exclusionary

\section{$\underline{2002}$}

Natl. Academy of Arbitrators

Collusive

Amer. Inst. for Conservation

Collusive

System Health Providers

Collusive

Professionals in Women's Care

Collusive

Biovail / Elan (Generic Adalat CC)

Collusive

Physician Integrated Systems

Collusive

Aurora Assn. Primary Care Phys

Collusive

Biovail / Tiazac

Exclusionary

Napa County OB/Gyns

Collusive

Rambus, Inc.

Exclusionary

\section{$\underline{2001}$}

Polygram Holding Inc. (The Three Tenors)

Collusive

\section{$\underline{2000}$}

Schering-Plough / Upsher Smith ${ }^{125}$

Exclusionary

\footnotetext{
${ }^{124}$ These were 3 separate but related complaints.
} 
MCC Manufacturers

Alaska Healthcare Network

MAP Policies of Prerecorded

Texas Surgeons

Colegio de Cirujanos Dentistas de PR

Abbott / Invamed

McCormick Spices

WI Chiropractic Assn

Nine West Group Inc

Andrx-Hoechst Generic Cardizem

\section{$\underline{1999}$}

Southern Valley Pool Assn.

Tahoe Health System

\section{8}

Asociacion de Farmacias Region

Columbia River Pilots Assn

Dentists of Juana Diaz, Coamo,

Chrysler Dealers, Unn

South Lake Tahoe Lodging Asso

M.D. Physicians of Southwest LA Inc

Institutional Pharmacy Network

Fastline Publications, Inc.

Great Lakes Chemical Corporation

Container Board Mfrs

Sensormatic

Urological Stone Surgeons, Inc

Mylan Pharmaceuticals, Inc.

Intel Corp

Summit Technology

\section{7}

American Cyanamid

College of Physicians

Mesa County Physicians, IPA
Collusive/Exclusionary

Collusive

Collusive

Collusive

Collusive

Exclusionary

Exclusionary

Collusive

Collusive (RPM)

Exclusionary

Collusive/Exclusionary

Collusive

Collusive

Exclusionary

Collusive

Exclusionary

Collusive

Collusive

Collusive

Collusive (RPM)

Collusive

Collusive

Collusive

Collusive

Exclusionary

Exclusionary

Collusive

Collusive (RPM)

Collusive

Collusive

Collusive/Exclusionary

Exclusionary

${ }^{125}$ The complaint was filed in April 2001, but while Robert Pitofsky was still Chair. Therefore, I have counted it as a Clinton case and placed in this list under 2000 for convenience. 
New Balance Athletic Shoe Inc.

Precision Moulding

RxCare

Toys "R" Us, Inc.

\section{$\underline{1995}$}

Dell Computer Inc

New England Juvenile Retailers

Baby Furniture Plus

Medical Staff of Good Samaritan

Del Monte Foods Company

La Asociacion Medica De Puerto Rico

Korean Video Store Ass'n of Maryland

Reebok

Physicians Group

The Council of Fashion Designers of America

Summit Communication Group

Port Washington Real Estate Board, Inc.

Federal News Service Group, Inc.

Reuters America Inc.

Santa Clara County Motor Car Dealers Association

\section{$\underline{1994}$}

Arizona Automobile Dealers Assoc

Community Associations Institute

Keds Corp.

McLean County Chiropractic Assoc

Personal Protective Armor Assoc

American Association of Language Specialists

American Society of Interpreters

Boulder Ridge Cable TV

Certain Home Oxygen/Home Oxygen

Homecare Oxygen \& Medical Equipment Company

Trauma Associates of North Broward, Inc.

International Association of Conference Interpreters
Collusive (RPM)

Collusive

Collus/Exclusion(MFN)

Exclusionary

Exclusionary

Collusive/Exclusionary

Exclusionary

Exclusionary

Collusive

Collusive/Exclusionary

Collusive

Collusive (RPM)

Collusive

Collusive

Collusive

Exclusionary

Collusive

Collusive

Exclusionary

Collusive

Collusive

Collusive (RPM)

Collusive

Collusive

Collusive

Collusive

Collusive

Exclusionary

Exclusionary

Collusive

Collusive

\section{$\underline{1993}$}

AE Clevite

American Industrial Real Estate Assoc.

Assoc. of Soil \& Foundation Engineers (ASFE)

B\&J School Bus Services Inc.

Baltimore Metropolitan Pharmaceutical Assoc, Inc.
Collusive

Exclusionary

Collusive

Collusive

Exclusionary 
National Assoc of Social Workers

Collusive

Southeast Colorado Pharmacal Assoc

Collusive

United Real Estate Brokers of Rockland, Ltd

Exclusionary

YKK (U.S.A)

Collusive

California Dental Association

Collusive

Nat'l Assoc of Prof Engineers

Collusive 